\title{
NAADP Receptors
}

\author{
Antony Galione \\ Department of Pharmacology, University of Oxford, Oxford OX1 3QT, United Kingdom \\ Correspondence: antony.galione@pharm.ox.ac.uk
}

Of the established $\mathrm{Ca}^{2+}$-mobilizing messengers, NAADP is arguably the most tantalizing. It is the most potent, often efficacious at low nanomolar concentrations, and its receptors undergo dramatic desensitization. Recent studies have identified a new class of calcium-release channel, the two-pore channels (TPCs), as the likely targets for NAADP regulation, even though the effect may be indirect. These channels localized at endolysosomes, where they mediate local $\mathrm{Ca}^{2+}$ release, and have highlighted a new role of acidic organelles as targets for messenger-evoked $\mathrm{Ca}^{2+}$ mobilization. Three distinct roles of TPCs have been identified. The first is to effect local $\mathrm{Ca}^{2+}$ release that may play a role in endolysosomal function including vesicular fusion and trafficking. The second is to trigger global calcium release by recruiting $\mathrm{Ca}^{2+}$-induced $\mathrm{Ca}^{2+}$-release $(\mathrm{CICR})$ channels at lysosomal-endoplasmic reticulum (ER) junctions. The third is to regulate plasma membrane excitability by the targeting of $\mathrm{Ca}^{2+}$ release from appropriately positioned subplasma membrane stores to regulate plasma membrane $\mathrm{Ca}^{2+}$-activated channels. In this review, I discuss the role of nicotinic acid adenine nucleotide diphosphate (NAADP)-mediated $\mathrm{Ca}^{2+}$ release from endolysosomal stores as a widespread trigger for intracellular calcium signaling mechanisms, and how studies of TPCs are beginning to enhance our understanding of the central role of lysosomes in $\mathrm{Ca}^{2+}$ signaling.

$\mathrm{C}$ alcium is the most evolutionarily ubiquitous of intracellular signals and controls cellular mechanisms as diverse as cellular motility, membrane fusion, ion channel function, enzyme activity, and gene expression (Berridge et al. 2003). Free cytoplasmic calcium levels are kept under tight control by pumps, exchangers, and buffering mechanisms including storage by organelles (Pozzan et al. 1994). $\mathrm{Ca}^{2+}$ signals may be elicited when these mechanisms are transiently overwhelmed by the opening of calcium-permeable channels at the plasma membrane or in membranes of calcium-storing organelles. Chronic activation of such channels may lead to cell death, for example, through the activation of apoptotic signaling cascades (Berridge et al.

1998). Many cell surface receptors are linked to signaling pathways that lead to the mobilization of calcium from intracellular storage organelles through the activation of specific $\mathrm{Ca}^{2+}$-release channels (Clapham 2007). Three major small molecule intracellular messengers have been established to link cell stimulation with organellar $\mathrm{Ca}^{2+}$ release: inositol trisphosphate $\left(\mathrm{IP}_{3}\right)$, cyclic adenosine diphosphate ribose (cADPR), and nicotinic acid adenine nucleotide diphosphate (NAADP) (Bootman et al. 2002). In addition, there have been reports that sphingosine 1 phosphate may activate a novel $\mathrm{Ca}^{2+}$-release mechanism (Mao et al. 1996; Schnurbus et al. 2002; Cavalli et al. 2003), whereas leukotriene $\mathrm{B}_{4}$ may activate, and arachidonic acid may inhib-

Editors: Geert Bultynck, Martin D. Bootman, Michael J. Berridge, and Grace E. Stutzmann

Additional Perspectives on Calcium Signaling available at www.cshperspectives.org

Copyright (C) 2019 Cold Spring Harbor Laboratory Press; all rights reserved; doi: 10.1101/cshperspect.a035071

Cite this article as Cold Spring Harb Perspect Biol 2019;11:a035071 
A. Galione

it ryanodine receptors (Striggow and Ehrlich 1997).

\section{DISCOVERY OF NAADP AS A $\mathrm{Ca}^{2+}$-MOBILIZING MOLECULE}

NAADP was discovered as a contaminant of commercial batches of $\beta-\mathrm{NADP}^{+}$by Lee and colleagues while investigating the effects of various pyridine nucleotides on calcium release from sea urchin egg homogenates (Clapper et al. 1987). The rationale for this was that at fertilization, in sea urchin eggs, dramatic changes in pyridine nucleotide levels occur (Epel 1964) with a similar time course to the generation of the calcium wave. Egg homogenates can be simply prepared from sea urchin eggs and are remarkably stable, even after freezing. They sequester calcium, and robustly release it when challenged with messengers and drugs (Morgan and Galione 2008). Three distinct calcium-release mechanisms were demonstrated. These were the early days of $\mathrm{IP}_{3}$, the founding $\mathrm{Ca}^{2+}$-mobilizing messenger that was demonstrated to link cell membrane receptors with $\mathrm{Ca}^{2+}$ mobilization (Streb et al. 1983). Soon afterward, $\mathrm{IP}_{3}$ was shown to activate sea urchin eggs (Whitaker and Irvine 1984) and to release calcium from sea urchin egg homogenate microsomal stores (Clapper and Lee 1985). In addition, two pyridine nucleotide metabolites were found to release $\mathrm{Ca}^{2+}$ from different subcellular nonmitochondrial fractions from egg homogenate: an enzyme-activated metabolite related to $\mathrm{NAD}^{+}$, subsequently identified as cyclic adenosine dinucleotide phosphate (cADPR) (Lee et al. 1989), and alkaline-treated NADP, later shown to be NAADP (Fig. 1; Lee and Aarhus 1995). A key feature of each $\mathrm{Ca}^{2+}$-mobilizing mechanism is their display of homologous desensitization (i.e., saturating, but nonoverlapping $\mathrm{Ca}^{2+}$ release in response to $\mathrm{IP}_{3}$, $\mathrm{CADPR}$, or NAADP), underscoring the independence of each of the three mechanisms in this broken cell system.

\section{NAADP AS A Ca ${ }^{2+}$-MOBILIZING MESSENGER}

NAADP is the most potent of $\mathrm{Ca}^{2+}$-mobilizing messengers described, being typically efficacious

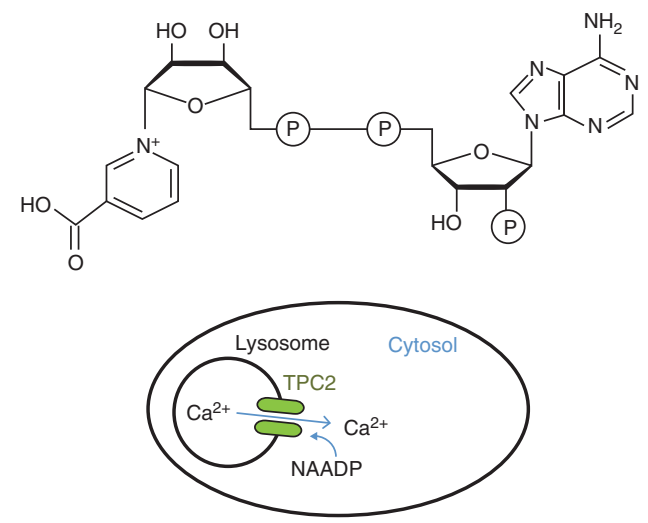

Figure 1. Structure and function of nicotinic acid adenine nucleotide diphosphate (NAADP). NAADP differs from $\beta$-NADP in that that the base nicotinic acid is substituted for nicotinamide (upper panel). NAADP, unlike NADP, is a potent $\mathrm{Ca}^{2+}$-mobilizing agent and activates two-pore channels in the membranes of lysosomes (lower panel).

at pico- or low nanomolar concentrations. A growing number of cellular stimuli and cell surface receptors have been found to be coupled to increases in NAADP levels, confirming its role as an intracellular messenger (Churchill et al. 2003; Masgrau et al. 2003; Rutter 2003; Yamasaki et al. 2005; Galione 2006; Gasser et al. 2006; Kim et al. 2008; Pandey et al. 2009; Rah et al. 2010; BarcelóTorns et al. 2011; Esposito et al. 2011; Lewis et al. 2012; Park et al. 2015). Mediation of calcium signaling by NAADP has been implicated by two approaches: inhibition of agonist-evoked calcium signals by prior self-inactivation of the NAADP receptor (Cancela et al. 1999) or NAADP receptor pharmacological blockers (Naylor et al. 2009; Zhang et al. 2018) and measurements of cellular NAADP levels in response to stimuli. Measurements of NAADP have been performed using either a radioreceptor assay, based on the high-affinity NAADP-binding protein of sea urchin eggs (Churchill et al. 2003; Churamani et al. 2004; Lewis et al. 2007), or by using a cycling assay of coupled enzyme reactions resulting in fluorescent resorufin production (Graeff and Lee 2002). Although some receptors appear to couple to NAADP production selectively, increasingly it is becoming apparent that receptors couple to 
multiple $\mathrm{Ca}^{2+}$-mobilizing messengers (Cancela et al. 2002; Aley et al. 2010) and this may be the norm.

NAADP may be synthesized from NADP by ADP-ribosyl cyclases, which are multifunctional enzymes that also cyclize NAD to cADPR (Malavasi et al. 2008). CD38 is a transmembrane ectoenzyme, but is also associated with intracellular compartments, and can catalyze the production of both CADPR and NAADP. It has been reported that the $\mathrm{CD} 38$ molecule may exist in two orientations with respect to its catalytic domain: cytosolic (type 3 ) or the more common luminal/extracellular (type 2) (Liu et al. 2017). The predominant mammalian ADP-ribosyl cyclase is CD38 (Ferrero et al. 2014), and there are several studies demonstrating the requirement of CD38 for NAADP synthesis in different cell types (Lee 2011; Lee et al. 2015; Lin et al. 2017). However, this is not seen in all cases (Soares et al. 2007), and CD38 has also been proposed to metabolize NAADP (Graeff et al. 2006; Schmid et al. 2011) in addition to phosphatases (Berridge et al. 2002a; Schmid et al. 2012). Because the proposed mechanism that the base-exchange of nicotinic acid for nicotinamide in the catalysis of NAADP formation from NADP is favored at acidic $\mathrm{pH}$, it is interesting that endolysosomaltargeted CD38 is more efficient for intracellular synthesis of NAADP (Fang et al. 2018). It has been proposed that stimuli may control substrate flux across vesicular membrane to regulate messenger synthesis (Davis et al. 2008; Fang et al. 2018) and synthesis may even be regulated by internalized receptors in the endosomal system (Brailoiu et al. 2011). A remarkable finding from an exocrine pancreatic cell line that lacks CD38 is that CCK receptors in these cells are linked to $\mathrm{Ca}^{2+}$ signaling through $\mathrm{IP}_{3}$-dependent mechanisms, but on expression of exogenous CD38 they switch from $\mathrm{IP}_{3}$ to NAADP signaling pathways (Cosker et al. 2010).

\section{$\mathrm{Ca}^{2+}$ STORES TARGETED BY NAADP}

Accumulating evidence suggests that the primary $\mathrm{Ca}^{2+}$ stores targeted by NAADP are separate from the endoplasmic reticulum (ER) and are members of a group of vesicles known as acidic organelles. The initial evidence for this came from the study of sea urchin eggs and was subsequently extended to mammalian cells.

\section{Sea Urchin Eggs}

The initial report of NAADP-evoked $\mathrm{Ca}^{2+}$ release using alkaline-activated NADP demonstrated that the responsive subcellular fraction in egg homogenates was largely separate from the microsomal/ER fraction sensitive to $\mathrm{IP}_{3}$ and CADPR (Clapper et al. 1987). Abrogation of $\mathrm{Ca}^{2+}$ storage by the ER by the SERCA inhibitor thapsigargin, while inhibiting $\mathrm{Ca}^{2+}$ release by either $\mathrm{IP}_{3}$ or $\mathrm{CADPR}$, only partially reduced $\mathrm{Ca}^{2+}$ release evoked by NAADP in both sea urchin egg homogenates (Genazzani and Galione 1996) and intact eggs (Churchill and Galione 2001a). Visualization of two separate $\mathrm{Ca}^{2+}$ stores was observed in elegant sea urchin egg stratification studies (Lee and Aarhus 2000). Stratification of intact eggs by centrifugation results in the formation of elongated structures with different organelles separating to different "poles." Uniform photolysis of caged derivatives of $\mathrm{Ca}^{2+}$-mobilizing messengers resulted in $\mathrm{IP}_{3}$ and cADPR mobilizing $\mathrm{Ca}^{2+}$ from the nuclear pole where ER accumulated, whereas NAADP released $\mathrm{Ca}^{2+}$ from the opposite end of the structure. These experiments are consistent with the primary $\mathrm{Ca}^{2+}$ store targeted by NAADP being distinct from the ER.

In a series of important experiments using pharmacological analyses and subcellular fractionation, lysosomal-related organelles were implicated as the primary target organelle for NAADP-evoked $\mathrm{Ca}^{2+}$ release in sea urchin eggs (Churchill et al. 2002). Acidic stores, such as lysosomes, have been shown to sequester $\mathrm{Ca}^{2+}$ by mechanisms dependent on their low luminal $\mathrm{pH}$ (Patel and Docampo 2010). Inhibition of the vacuolar $\mathrm{H}^{+}$-ATPase by bafilomycin decreases proton uptake into acidic stores, and if their membranes are sufficiently leaky to protons this leads to the alkalinization of their lumen. Uptake of $\mathrm{Ca}^{2+}$ into these stores appears to be dependent on the maintenance of the proton gradient, because bafilomycin and protonophores inhibit $\mathrm{Ca}^{2+}$ storage by these organelles, 
A. Galione

although the detailed mechanisms are not well understood. Invertebrates and lower vertebrates express a $\mathrm{Ca}^{2+} / \mathrm{H}^{+}$exchanger (CAX), which may play a role in $\mathrm{Ca}^{2+}$ sequestration in their analogous organelles (Melchionda et al. 2016). The role for proton gradients in lysosomal $\mathrm{Ca}^{2+}$ uptake has been questioned based on the apparent lack of effects of bafilomycin in some cells (Garrity et al. 2016); however, the leakiness of acidic stores to both protons and $\mathrm{Ca}^{2+}$ is variable and needs to be taken into account. A dense membrane fraction from sea urchin egg homogenates was isolated from a Percoll gradient and consisted of "reserve granules." This fraction was enriched with lysosomal markers and supported ATP-dependent $\mathrm{Ca}^{2+}$ sequestration that was inhibited by preincubation with bafilomycin or the protonophore, nigericin, but not thapsigargin (Churchill et al. 2002). This fraction was found to contain $\left[{ }^{32} \mathrm{P}\right]$ NAADP-binding sites, and displayed NAADP-evoked $\mathrm{Ca}^{2+}$ release, but was not responsive to $\mathrm{IP}_{3}$ or $\mathrm{CADPR}$. Reserve granules from sea urchin eggs are lysosome-related organelles. In intact sea urchin eggs, treatment with the lysosomotropic agent, glycyl-phenylalanine 2-naphthylamide (GPN), caused the reversible lysis of lysotracker-stained vesicles, resulting in a series of small amplitude cytoplasmic $\mathrm{Ca}^{2+}$ signals, consistent with their role as $\mathrm{Ca}^{2+}$ stores. Importantly, GPN treatment in either intact eggs or egg homogenates selectively abolished NAADP-evoked $\mathrm{Ca}^{2+}$ release with little effect on $\mathrm{Ca}^{2+}$ release by either $\mathrm{IP}_{3}$ or $\mathrm{CADPR}$. From these data, it was proposed that in sea urchin eggs the primary target of NAADP is acidic stores rather than the ER. These findings would not support a recent assertion that GPN, as a weak base, may primarily work by directly releasing $\mathrm{Ca}^{2+}$ from the ER (Atakpa et al. 2019). Consistent with this, experiments using sea urchin egg homogenates using luminal $\mathrm{pH}$ indicators such as acridine orange or lysosensor also have demonstrated that NAADP, uniquely among $\mathrm{Ca}^{2+}$ mobilizing messengers, also causes the alkalinization of the lumen of responsive vesicles, representing another possible signaling mechanism for this molecule (Morgan and Galione 2007b). It has recently been proposed that a major source of $\mathrm{Ca}^{2+}$ for filling of lysosomes comes from the ER, which forms close appositions at membrane contact sites (Garrity et al. 2016). In particular, the importance of $\mathrm{IP}_{3} \mathrm{R}$-mediated $\mathrm{Ca}^{2+}$ release has been emphasized (Atakpa et al. 2018).

\section{Mammalian Cells}

Following these studies in sea urchin eggs, it was shown that NAADP also targeted acidic stores in a wide range of mammalian cells, and in response to a variety of cellular stimuli (Mitchell et al. 2003; Kinnear et al. 2004; Yamasaki et al. 2004; Galione 2006; Gerasimenko et al. 2006, 2015; Menteyne et al. 2006; Zhang et al. 2006, 2010; Macgregor et al. 2007; Gambara et al. 2008; Jardín et al. 2008; Kim et al. 2008; Lloyd-Evans et al. 2008; Brailoiu et al. 2009b, 2010b; Pandey et al. 2009; Thai et al. 2009; Cosker et al. 2010; Dickinson et al. 2010; Tugba Durlu-Kandilci et al. 2010; Davis et al. 2012; Capel et al. 2015; Lin et al. 2017; Foster et al. 2018).

\section{DESENSITIZATION OF NAADP-EVOKED $\mathrm{Ca}^{2+}$ RELEASE}

The $\mathrm{Ca}^{2+}$-release mechanism activated by NAADP shows unusual and profound inactivation properties. One major area of confusion in this field is that the inactivation properties of $\mathrm{Ca}^{2+}$ release varies markedly between sea urchin egg and mammalian systems, which we have termed type 1 and type 2, respectively (Fig. 2; Morgan and Galione 2008).

\section{Sea Urchin Eggs}

The initial report demonstrating the efficacy of NAADP as a $\mathrm{Ca}^{2+}$-mobilizing molecule showed that NAADP released $\mathrm{Ca}^{2+}$ by a mechanism independent of $\mathrm{IP}_{3}$ or ryanodine receptors (RyRs), based on each of these mechanisms showing homologous desensitization (Lee and Aarhus 1995). Such desensitization occurs at the level of release mechanisms rather than on account of $\mathrm{Ca}^{2+}$ store depletion. After NAADP stimulated $\mathrm{Ca}^{2+}$ release in egg homogenates, they became refractory to subsequent challenge with NAADP, but still responded to either $\mathrm{IP}_{3}$ or 
NAADP Receptors

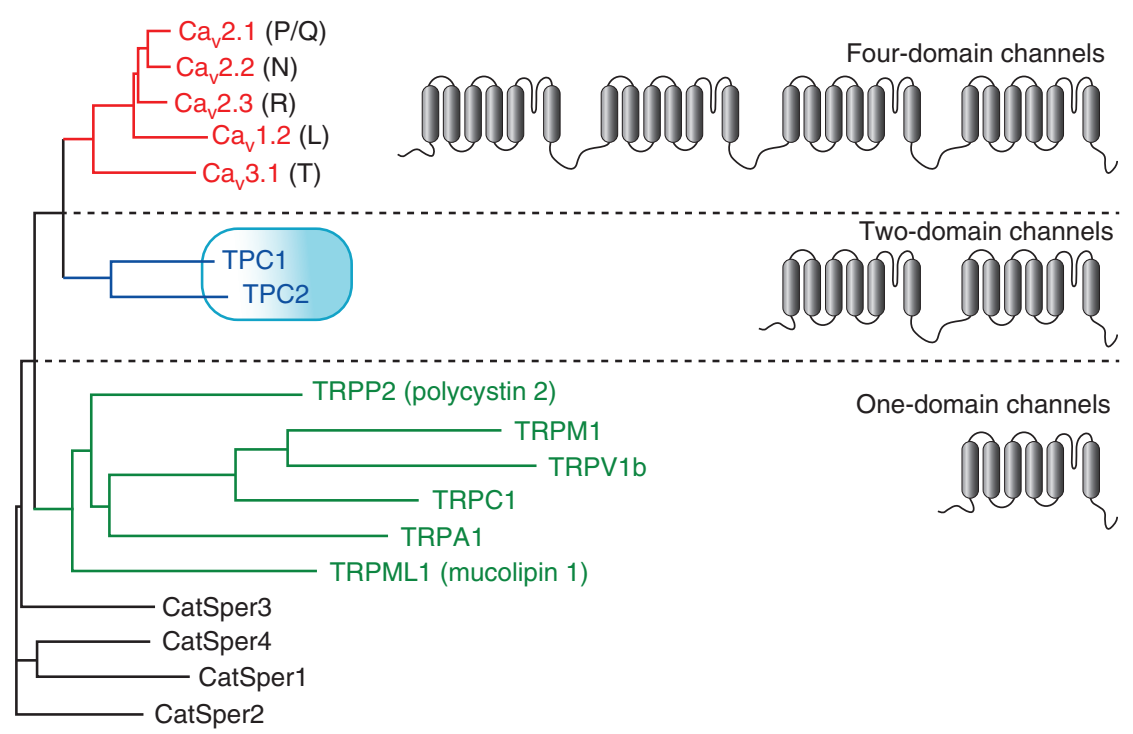

Figure 2. Phylogenetic tree for human two-pore channels (TPCs) and their relationship with voltage-gated $\mathrm{Ca}^{2+}$ channels (VGCCs) and transient receptor potential (TRP) members. It is likely that VGCCs have arisen from two rounds of tandem duplication in evolution. Thus, TPCs, having 12 transmembrane domains (12TM) may be considered ancient intermediate proteins between TRP channels (6TM), such as CatSpers in sperm or mucolipins or polycystins, and VGCCs (24TM).

cADPR. This was the first piece of evidence that NAADP activated a novel $\mathrm{Ca}^{2+}$-release channel, distinct from the principal $\mathrm{Ca}^{2+}$-release channels on the ER.

Further analysis of the phenomenon of selfinactivation of NAADP-evoked $\mathrm{Ca}^{2+}$ release in sea urchin eggs and homogenates revealed several profound and unusual features. A surprising finding was that picomolar concentrations of NAADP, although subthreshold for triggering $\mathrm{Ca}^{2+}$ release in egg homogenates, were able to inactivate completely the NAADP $\mathrm{Ca}^{2+}$-release mechanism to a subsequent challenge by nanomolar concentration of NAADP that would normally evoke a maximal $\mathrm{Ca}^{2+}$ release (Aarhus et al. 1996; Genazzani et al. 1996). The extent of inactivation was dependent on both the concentration and duration of incubation (Genazzani et al. 1996, 1997b). Mechanisms of inactivation of the NAADP receptor or NAADP-sensitive $\mathrm{Ca}^{2+}$-release channel complex are not understood, but may be related to the apparent irreversible binding of $\left[{ }^{32} \mathrm{P}\right]$ NAADP. The radioligand appears to become occluded on binding in a time-dependent manner (Aarhus et al.
1996), which requires $\mathrm{K}^{+}$ions (Dickinson and Patel 2003). Studies with the selective NAADP receptor antagonist, Ned-19 (Naylor et al. 2009) and its analogs (Rosen et al. 2009), have led to the proposal that there are two distinct binding sites for NAADP. The first is high affinity, whose occupancy leads to slow inactivation of the receptor, and a second lower affinity site that leads to rapid channel opening. The structurally related compound Ned-20 blocks inactivation of $\mathrm{Ca}^{2+}$ release by NAADP, but not its activation (Rosen et al. 2009).

\section{Mammalian Cells}

There are key differences between desensitization of the NAADP receptor between sea urchin eggs and mammals. As discussed above, subthreshold concentrations of NAADP can fully inactivate the NAADP-sensitive $\mathrm{Ca}^{2+}$-release mechanism in sea urchin eggs, whereas in a mammalian cell, high concentrations of NAADP are needed for full inactivation, which can occur in the apparent absence of receptor activation. The first report of NAADP action as a 
$\mathrm{Ca}^{2+}$-mobilizing agent in a mammalian cell was in the pancreatic acinar cell (Cancela et al. 1999), which was also the system in which $\mathrm{IP}_{3}$ was first demonstrated to mobilize $\mathrm{Ca}^{2+}$ from nonmitochondrial stores (Streb et al. 1983). Using whole-cell patch clamping and measuring $\mathrm{Ca}^{2+}$-activated currents, we found that a pipette concentration of $10 \mu \mathrm{M}$ NAADP failed to elicit any responses. However, we noticed that after intracellular application of this concentration of NAADP, cholecystokinin (CCK), which usually mobilizes $\mathrm{Ca}^{2+}$ stores at picomolar concentrations, now failed to evoke any response. We speculated that we had inactivated the NAADPevoked $\mathrm{Ca}^{2+}$-release mechanism that could be a key component of the CCK signal transduction mechanism. We therefore tried a range of NAADP and found that concentrations of NAADP as low as $50 \mathrm{~nm}$ in the pipette, elicited robust oscillatory responses, similar to those evoked by CCK in non-NAADP-treated cells. The concentration-response relationship for NAADP appears "bell-shaped," with maximal $\mathrm{Ca}^{2+}$ responses occurring at around $100 \mathrm{nM}$ NAADP, whereas [NAADP] higher than $1 \mu \mathrm{M}$ were without effect. Using caged NAADP, we showed that photolysis of this compound also evoked a series of spikes in $\mathrm{Ca}^{2+}$-activated currents, which were suppressed in the presence of supramicromolar concentrations of free NAADP in the patch pipette. Bell-shaped concentration-response curves seem to be a major hallmark of mammalian NAADP-induced $\mathrm{Ca}^{2+}$ release. A subsequent study in a Jurkat $\mathrm{T}$-cell line, showed that maximal $\mathrm{Ca}^{2+}$ release occurred on microinjection of $\sim 100 \mathrm{~nm}$ NAADP, with concentrations of $>1 \mu \mathrm{M}$ failing to elicit any response per se, while inhibiting $\mathrm{T}$-cell receptor activation (Berg et al.2000). A number of further studies in different cell types used this "prior NAADP-induced inactivation" phenomenon to implicate NAADP in the $\mathrm{Ca}^{2+}$-signal transduction pathways activated by various stimuli in the absence of selective NAADP antagonists at that time. These include glucose-evoked $\mathrm{Ca}^{2+}$ spiking in MIN6 cells (Masgrau et al. 2003), endothelin 1-evoked $\mathrm{Ca}^{2+}$ release in pulmonary vascular smooth myocytes (Kinnear et al. 2004), $\beta_{1}$ adrenoreceptor enhancement of $\mathrm{Ca}^{2+}$ signal- ing and contractility in ventricular cardiac myocytes (Macgregor et al. 2007), and mGluR1 signaling in hippocampal neurones (Foster et al. 2018).

\section{PHARMACOLOGICAL PROPERTIES OF NAADP RECEPTORS}

The pharmacology of NAADP-evoked $\mathrm{Ca}^{2+}$ release, initially investigated in sea urchin egg systems, demonstrated major differences with the known $\mathrm{Ca}^{2+}$-release mechanisms in the ER. In egg homogenates, NAADP-evoked $\mathrm{Ca}^{2+}$ release was not affected by either the competitive $\mathrm{IP}_{3} \mathrm{R}$ inhibitor heparin, nor by ryanodine or 8-substituted CADPR analogs that antagonize RyR-mediated $\mathrm{Ca}^{2+}$ release. An initial report that thio-NADP was a selective antagonist of NAADP (Chini et al. 1995) was subsequently explained by inactivation of the NAADP-sensitive $\mathrm{Ca}^{2+}$-release mechanism by traces of contaminating NAADP (Dickey et al. 1998).

A number of channel blockers were found to inhibit NAADP-evoked $\mathrm{Ca}^{2+}$ release selectively in sea urchin egg homogenates with little effect on either $\mathrm{IP}_{3-}$ or $\mathrm{CADPR}$-mediated $\mathrm{Ca}^{2+}$ release (Genazzani et al. 1997a). These antagonists included voltage-gated $\mathrm{Ca}^{2+}$ channel (VGCC) blockers such as diltiazem, nifedipine, and D600 (although higher concentrations were required to block NAADP-evoked $\mathrm{Ca}^{2+}$ release than VGCCs). Purinoceptor antagonists such as PPADS also display a degree of NAADP antagonism (Billington and Genazzani 2007). Because the NAADP receptor effectively discriminates between NAADP and NADP, which differs only by the substitution of a nicotinic acid moiety instead of nicotinamide, nicotinic acid analogs were developed that antagonize NAADPinduced $\mathrm{Ca}^{2+}$ release. These include CMA008 (Dowden et al.2006) and BZ194 (Dammermann et al. 2009), which also have the advantage that they are membrane permeant. A series of novel compounds have been identified by in silico screening strategies based on the three-dimensional shape and electrostatic properties of NAADP that are the most potent of NAADP antagonists developed so far (Naylor et al. 
2009; Rosen et al. 2009). Ned-19, the founding member of these analogs, is becoming the most widely used antagonist because of its reasonable potency, membrane permeability, and selectivity (Naylor et al. 2009; Rosen et al. 2009; Thai et al. 2009; Aley et al. 2010). A recent study suggested that Ned-19 was not able to inhibit NAADPevoked $\mathrm{Ca}^{2+}$ release in sea urchin egg homogenates, although only concentrations lower than 1.6 $\mu \mathrm{M}$ were tried (Ali et al. 2014).

Interestingly, Ned-19 analogs have been used to dissect the activation and inactivation effects of NAADP at the sea urchin egg NAADP receptor (Rosen et al. 2009). Ned-20, which differs only from Ned-19 by the para rather than ortho position of a fluorine, prevents the inactivation of NAADP-sensitive $\mathrm{Ca}^{2+}$-release mechanism by subthreshold NAADP concentrations, without affecting NAADP-evoked $\mathrm{Ca}^{2+}$ release by higher NAADP concentrations. Ned-20 also inhibits high-affinity $\left[{ }^{32} \mathrm{P}\right]$ NAADP binding to egg membranes (Rosen et al. 2009). These findings are consistent with multiple binding sites for the sea urchin egg NAADP receptor, with highaffinity sites leading to inactivation and lower affinity sites enabling activation.

Recent structure-activity relationships of NAADP analogs suggest some differences between NAADP-binding sites between sea urchin egg and those of mammalian cells (Ali et al. 2014). Recent screening campaigns aimed at finding new antiviral agents have focused on $\mathrm{Ca}^{2+}$ channel inhibitors, because lysosomal $\mathrm{Ca}^{2+}$ fluxes are required for Ebola (Sakurai et al. 2015) or MERS virus (Gunaratne et al. 2018 b) egress from the lysosomal lumen into the cytoplasm (Sakurai et al. 2015). These have highlighted a range of repurposed drugs that also inhibit NAADP-mediated $\mathrm{Ca}^{2+}$ release $(\mathrm{Gu}-$ naratne et al. 2018a; Penny et al. 2018).

\section{TWO-PORE CHANNELS}

A family of novel intracellular channels termed two-pore channels (TPCs) have emerged as the leading candidates for NAADP-gated $\mathrm{Ca}^{2+}$-release channels. The founding member of this family, TPC1, was cloned in 2000 from a rat kidney cDNA library in a search for novel mem- bers of voltage-gated cation channels (Ishibashi et al. 2000). The putative channel had only a $20 \%$ homology with the transmembrane domains of the $\alpha$ subunit of voltage-gated $\mathrm{Na}^{+}$and $\mathrm{Ca}^{2+}$ channels, but the highest homology was with a deposited sequence of a putative $\mathrm{Ca}^{2+}$ channel from the plant Arabidopsis thaliana. Subsequent analysis of the plant clone, AtTPC1, implicated a role for this protein in $\mathrm{Ca}^{2+}$ transport and signaling when expressed in yeast and Arabidopsis (Furuichi et al. 2001), and a role in germination and stomatal physiology as a component of the slow vacuolar channel (Peiter et al. 2005). The putative channel, rather than having four repeats of six transmembrane segments as for voltagegated $\mathrm{Na}^{+}$and $\mathrm{Ca}^{2+}$ channels, only has two. Thus, in effect, the protein is the equivalent of half a $\mathrm{Na}^{+}$or $\mathrm{Ca}^{2+}$ channel, and may represent an ancestral form, which has been duplicated later in evolution to give rise to the four domain channels (Fig. 3). In recent years, high-resolution X-ray crystallographic and cryo-electron microscope structures of these channels have been determined (Guo et al. 2016; Kintzer and Stroud 2016; Patel et al. 2016; She et al. 2018, 2019).

\section{ENDOLYSOSOMAL TWO-PORE CHANNELS AS TARGETS FOR NAADP}

Two clues as to the candidature of TPCs as NAADP-regulated channels emerged in the last few years. Michael Zhu, searching for novel transient receptor potential (TRP) family members in 2002, had cloned a second member of the TPC family, termed TPC2, and found that when heterologously expressed in HEK293 cells, it localized with the lysosomal marker, LAMP1. The second was the further analysis of AtTPC1 function by Sanders and colleagues, showing that AtTPC1 localized to plant vacuoles, the major plant acidic organelle and the functional equivalent of lysosomes in plants (Peiter et al. 2005). The localization of TPCs to acidic stores, and the partial pharmacological overlap of NAADPregulated channels with VGCCs (Genazzani et al. 1997a) and TRP channels (Moccia et al. 2006), which show homologies with TPCs, made these proteins credible candidates as the 
A. Galione

A

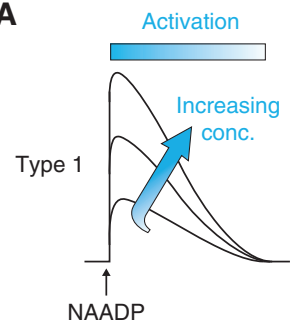

B

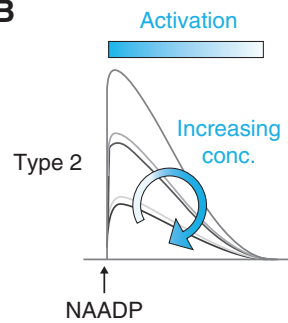

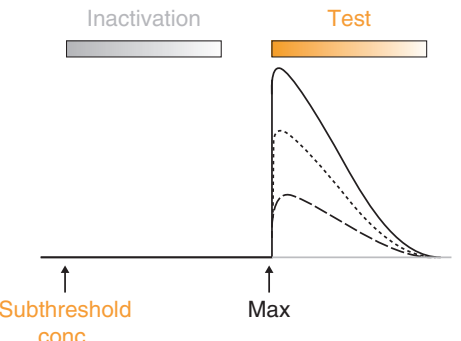

conc.

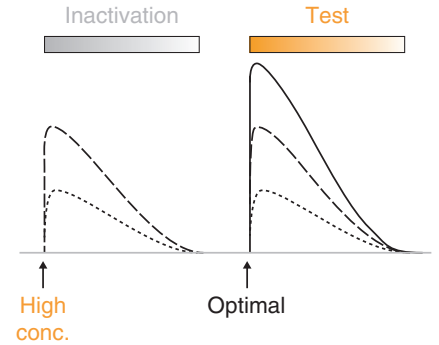

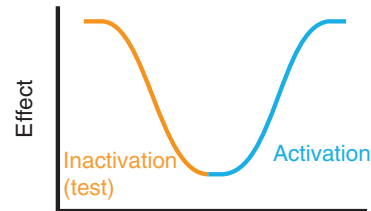

$\log (\mathrm{NAADP})$

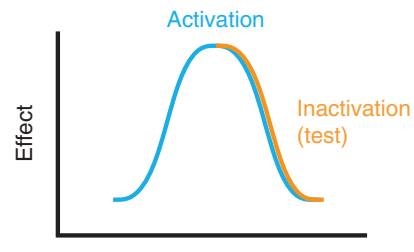

$\log (N A A D P)$

Figure 3. Differences between desensitization of mammalian and sea urchin nicotinic acid adenine nucleotide diphosphate (NAADP) receptors. (A) Desensitization of sea urchin NAADP receptors (type 1 desensitization). The blue left panel traces show stylized $\mathrm{Ca}^{2+}$ dye fluorescence traces in response to increasing concentrations (conc.) of NAADP, which increases $\mathrm{Ca}^{2+}$ release represented by a classical sigmoid log concentration-response curve (blue line, right panel). However, preincubation with subthreshold concentrations of NAADP, that do not evoke $\mathrm{Ca}^{2+}$ release, desensitize $\mathrm{Ca}^{2+}$ release in a time and concentration manner, by subsequent challenge by a normally maximal NAADP (test) concentration (middle panel, and orange curve, right panel). $(B)$ Desensitization of mammalian NAADP receptors (type 2 desensitization). Increasing concentrations of NAADP enhances $\mathrm{Ca}^{2+}$ release to a maximum (left and middle panels). Thereafter, increasing concentrations of NAADP evoke progressively smaller $\mathrm{Ca}^{2+}$ release to a point when no $\mathrm{Ca}^{2+}$ release is evoked at high NAADP concentrations. This "bell-shaped" or hormetic log concentration-response curve is shown in the right panel (blue curve).

elusive NAADP receptor. First, the subcellular localization of the human TPC1 and TPC2 isoforms in HEK293 cells was examined. In addition, because the genomes of many species, but not human or rodent, also express a third isoform, TPC3 (Cai and Patel 2010; Zhu et al. 2010), the chicken TPC3 was also expressed to examine its subcellular distribution in HEK293 cells (Calcraft et al. 2009). All three TPCs localize to the endolysosomal system with no apparent expression in Golgi, mitochondria, or ER. Only TPC2 consistently colocalized with the lysosomal marker, LAMP2, but not with early or late endosomal markers. In contrast, TPC1 and TPC3 predominantly were expressed in endosomal and other unidentified compartments, but with only sparse colocalization with lysosomal markers. In HEK293 cells, TPCs are endogenously expressed at low levels, and endogenous TPC2 was also immunolocalized to lysosomes. Overexpression of human TPC2 (HsTPC2) was associated with increased specific $\left[{ }^{32} \mathrm{P}\right] \mathrm{NAADP}$ binding to HEK293 cell membranes and immunoprecipitated TPC2 proteins. Both high- and low-affinity binding sites were manifest in membranes from TPC2-overexpressing cells with $K_{d}$ values of $5 \mathrm{~nm}$ and $7 \mu \mathrm{m}$, which are remarkably similar to endogenous binding in membranes from mouse liver, a tissue with particularly high expression of TPCs. Photolysis of caged NAADP in patched wild-type HEK293 cells elicited a small $\mathrm{Ca}^{2+}$ response. In cells stably overexpressing TPC2, a large biphasic $\mathrm{Ca}^{2+}$ response was evoked on NAADP uncaging or dialysis. An initial pacemaker-like ramp of $\mathrm{Ca}^{2+}$ was followed by a larger and faster transient $\mathrm{Ca}^{2+}$ re- 
lease. Bafilomycin treatment abolished both phases of the $\mathrm{Ca}^{2+}$ response, whereas the $\mathrm{IP}_{3} \mathrm{R}$ antagonist heparin blocked the second phase alone. This finding is consistent with the "trigger" hypothesis for a mode of NAADP action (Cancela et al. 1999), whereby NAADP evokes a localized $\mathrm{Ca}^{2+}$ signal by mobilizing bafilomycin-sensitive acidic stores, which is then globalized by recruiting $\mathrm{Ca}^{2+}$-induced $\mathrm{Ca}^{2+}$ release (CICR) from nearby $\mathrm{ER}$, in this case by activating $\mathrm{IP}_{3} \mathrm{Rs}$. The concentration-response relationship between NAADP and $\mathrm{Ca}^{2+}$ release was of the characteristic bell-shape for NAADP in mammalian cells, with maximal $\mathrm{Ca}^{2+}$ release occurring at between $10 \mathrm{~nm}$ and $1 \mu \mathrm{M}$, while $1 \mathrm{~mm}$ was without effect. Importantly, short hairpin RNA (shRNA) against TPC2 completely abolished to the ability of NAADP to release $\mathrm{Ca}^{2+}$. Although NAADP evoked activation of oscillatory $\mathrm{Ca}^{2+}$-dependent cation currents in pancreatic $\beta$ cells obtained from wild-type mice, this property of NAADP was abolished in pancreatic $\beta$ cells seen from $\mathrm{TPC}^{-/-}$cells.

In contrast to the overexpression of TPC2, we found that HEK cells stably expressing HsTPC1 evoked only a localized $\mathrm{Ca}^{2+}$ release in response to NAADP, which failed to globalize. One possibility is that the endosomal localization of TPC1 means that there is less close apposition with ER so that coupling with CICR channels is weaker. Two subsequent publications broadly confirmed these findings (Brailoiu et al. 2009a; Zong et al. 2009).

\section{PROPERTIES OF ENDOGENOUS TPCS FROM SEA URCHIN EGGS}

The properties of heterologously expressed mammalian TPCs made them strong candidates as NAADP receptors. However, most of the studies of NAADP-mediated $\mathrm{Ca}^{2+}$ release and $\left[{ }^{32} \mathrm{P}\right]$ NAADP-binding sites have been performed in sea urchin egg preparations, in which the $\mathrm{Ca}^{2+}$-mobilizing effects of NAADP were first discovered. It was important to ascertain whether sea urchin eggs express TPCs and whether they functioned as NAADP receptors. Screening of the genome of the sea urchin Strongylocentrotus purpuratus revealed three TPC isoforms, which were cloned from ovaries. These isoforms displayed $\sim 30 \%$ sequence homology between the isoforms (Brailoiu et al. 2010a; Ruas et al. 2010). Importantly, immunoprecipitation of TPCs from solubilized egg membranes using isoform-specific antibodies produced immunocomplexes that specifically bound $\left[{ }^{32} \mathrm{P}\right]$ NAADP with $K_{d}$ s of $\sim 1$ nM. Binding of $\left[{ }^{32} \mathrm{P}\right]$ NAADP to immunoprecipitated TPC isoforms mirrored all the key features of binding to intact egg membranes, including $\mathrm{K}^{+}$-dependent irreversibility and a similar binding selectivity for NAADP over NADP. These data provided compelling evidence that TPCs form complexes that can explain all the properties of $\left[{ }^{32} \mathrm{P}\right]$ NAADP-binding sites previously characterized from sea urchin egg preparations. It should be noted that solubilization of the $\left[{ }^{32} \mathrm{P}\right] \mathrm{NAADP}$-binding protein from native sea urchin egg membranes results in a protein complex substantially smaller than $\mathrm{IP}_{3} \mathrm{R}$ or RyR homotetramers (Berridge et al. 2002b). As with their mammalian homologs, heterologous expression of the sea urchin TPC1 and TPC2 isoforms in HEK293 cells enhanced NAADP-evoked $\mathrm{Ca}^{2+}$ release from acidic $\mathrm{Ca}^{2+}$ stores, which was amplified by recruitment of $\mathrm{IP}_{3} \mathrm{Rs}$, although coupling between TPC1 and $\mathrm{IP}_{3} \mathrm{Rs}$ appeared looser. In contrast, TPC3 actually suppressed the small NAADPevoked response observed in control cells and also abolished the enhancement in cells stably transfected with TPC2 (Fig. 4). This effect of TPC3 is puzzling for several reasons. The effect of TPC3 cannot be accounted by a general dysregulation of acidic $\mathrm{Ca}^{2+}$ stores because measurement of both $\mathrm{Ca}^{2+}$ storage and luminal $\mathrm{pH}$ do not appear to be altered in cells overexpressing TPC3. Another possibility is that TPC3 has a dominant negative effect, perhaps by forming heterodimers. This is likely because dimers constitute the proposed structure of functional TPCs. Indeed, homodimerization of human TPC2 has been reported (Zong et al. 2009; Rietdorf et al. 2011). However, given the differing subcellular localizations of each of the TPCs, at least when heterologously expressed, it is unclear whether heterodimerization can explain TPC3 suppression of NAADP-evoked $\mathrm{Ca}^{2+}$ release. 


\section{A. Galione}

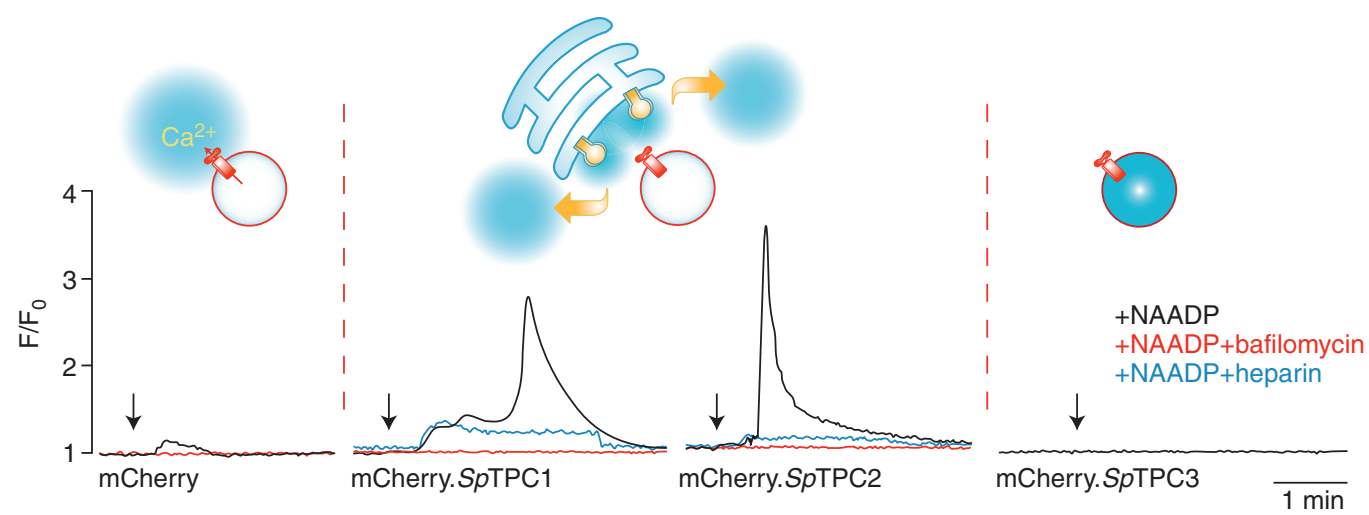

Figure 4. Nicotinic acid adenine nucleotide diphosphate (NAADP)-mediated $\mathrm{Ca}^{2+}$ release in HEK293 cells expressing each of the three sea urchin two-pore channel (TPC) isoforms. Representative $\mathrm{Ca}^{2+}$ traces of cells dialyzed with NAADP (100 nM) and fura-2 via patch pipette in whole-cell configuration, in absence or presence of bafilomycin $\mathrm{A} 1(1 \mu \mathrm{M})$ or the $\mathrm{IP}_{3} \mathrm{R}$ antagonist, heparin $(200 \mu \mathrm{g} / \mathrm{mL})$. Arrows indicate break-in. In wild-type cells, only a small endogenous response to NAADP was seen. In SpTPC1 and SpTPC2 cells, NAADP-evoked biphasic responses, the first component was from acidic stores (bafilomycin-sensitive), whereas the second phase, which requires the first to trigger it, is caused by the recruitment of $\mathrm{IP}_{3} \mathrm{Rs}$ (heparin-sensitive). TPC 3 expression suppresses the endogenous response. Models for NAADP-triggered $\mathrm{Ca}^{2+}$ responses, based on interaction between different organelles (circle, lysosome, and network, endoplasmic reticulum [ER]) are also shown above each series of traces.

\section{SINGLE-CHANNEL PROPERTIES OF HUMAN TPCs}

Although TPCs are emerging as promising candidates as NAADP-gated $\mathrm{Ca}^{2+}$-release channels in the endolysosomal system, it is important to characterize their biophysical channel properties to show that they do indeed function in this way. However, their localization in organelles presents several problems, because they are not readily amenable for electrophysiological analysis as for channels resident at the plasma membrane. Moreover, there is no evidence at present that they cycle to the plasma membrane as for other $\mathrm{Ca}^{2+}$-release channels (Taylor et al. 2009). The traditional way of studying organellar channels is their reconstitution into artificial bilayers for single-channel analysis, as exemplified for $\mathrm{IP}_{3} \mathrm{R}$ (Ehrlich and Watras 1988) and RyR (Lai et al. 1988) single-channel studies. However, for ER channels, nuclear envelope patching has gained increasing popularity (Mak and Foskett 1997; Wagner et al. 2014). In an early report of the electrophysiological characteristics of animal TPCs, immunopurified human TPC2 was reconstituted into lipid bilayers and shown to form NAADP-gated cation conductances (Pitt et al. 2010). Channels were generally silent until application of NAADP to the cis, or cytoplasmic, face of the bilayer. The channels showed a selectivity for cations with conductances of around $300 \mathrm{pS}$ and $15 \mathrm{pS}$ for $\mathrm{K}^{+}$and $\mathrm{Ca}^{2+}$ ions as the conducting species. Interestingly, NAADP sensitivity may be regulated by store filling with $\mathrm{Ca}^{2+}$, because NAADP sensitivity was markedly dependent on trans, or luminal, $\mathrm{Ca}^{2+}$, with the $\mathrm{EC}_{50}$ for NAADP-evoked enhancement of open probability decreasing from $500 \mathrm{~nm}$ to $5 \mathrm{~nm}$ as luminal $\mathrm{Ca}^{2+}$ increased to $200 \mu \mathrm{M}$. This is in the range of reported luminal free $\mathrm{Ca}^{2+}$ levels in lysosomes (Christensen et al. 2002; Lloyd-Evans et al. 2008). Thus, fluctuations in luminal $\mathrm{Ca}^{2+}$ attributed to cycles of release and uptake of $\mathrm{Ca}^{2+}$ could be important determinants of the effects of NAADP on $\mathrm{Ca}^{2+}$ release, offering one explanation for how constant NAADP levels may elicit trains of $\mathrm{Ca}^{2+}$ spikes, as widely observed in various cell types (Cancela et al. 1999). Another variable is luminal $\mathrm{pH}$ of acidic stores because NAADP has also 
NAADP Receptors

been found to alkalinize acidic stores in sea urchin eggs and homogenates (Morgan and Galione 2007a,b), and it is possible that luminal $\mathrm{pH}$ has significant effects on TPC2 channel properties. Importantly, the NAADP antagonist, Ned19, was also found to block singlechannel TPC2 currents (Pitt et al. 2010). However, it should be stressed here that although the immunopurified TPC complexes both form NAADP-gated $\mathrm{Ca}^{2+}$ channels (Pitt et al. 2010) and bind $\left[{ }^{32} \mathrm{P}\right]$ NAADP (Calcraft et al. 2009; Ruas et al. 2010), the possibility remains that NAADP could interact with an accessory protein of TPCs instead of a direct interaction with TPC proteins themselves (Galione et al. 2009).

A single-channel analysis of NAADP-gated channels has also been performed from lysosomal enriched fractions derived from liver (Zhang and $\mathrm{Li}$ 2007) and bovine coronary vascular smooth muscle (Zhang et al. 2009). These channels conducted $\mathrm{Cs}^{+}$, and were sensitive to NAADP with open probabilities displaying a bell-shaped concentration dependence, with maximum $\mathrm{P}_{\mathrm{o}}$ occurring at $1 \mu \mathrm{M}$ NAADP in both preparations. The pharmacology was consistent with previous studies of NAADP-evoked $\mathrm{Ca}^{2+}$ release, with block by VGCC antagonists, PPADS, and also amiloride. Interestingly, $\mathrm{P}_{\mathrm{o}}$ was increased at acidic $\mathrm{pH}$. In contrast to the situation in most mammalian cells examined so far, pretreatment with concentrations of NAADP as low as $0.5 \mathrm{~nm}$ blocked subsequent channel openings by higher NAADP concentrations, as seen for sea urchin egg receptors and in liver (Mándi et al. 2006). The identity of these channels was ascribed to mucolipin-1 (TRPML-1), a lysosomal TRP channel linked to the lysosomal storage disease, mucolipidosis IV, on the basis of a blocking effect of an anti-TPRML1 antibody and reduction of channel activity from cells treated with an siRNA TPRML1 construct. However, the identity of TRPML1 as an NAADP receptor candidate remains controversial (Pryor et al. 2006; Yamaguchi et al. 2011). In addition, a recent report suggests that NAADP may increase levels of a short variant of a TRPML2 transcript in lymphoid cells (Samie et al. 2009), underscoring the likely complex interactions between lysosomal channels.

\section{PATCH-CLAMPING LYSOSOMES}

Another development allowing electrophysiological characterization of NAADP-regulated ion currents across more native endolysosomal membranes have been three approaches to patch endolysosomal vesicles. The first is a planar patch-clamp method. Here, purified organelles are added to a glass chip for current recording (Schieder et al. 2010). The second is to excise enlarged organelles from cells and to patch them directly with a conventional patch-clamp technique (Wang et al. 2012). Both approaches require that lysosomes or endosomes are enlarged by chemicals such as vacuolin. Recently, chemical mixtures have been defined that selectively enlarge lysosomes and endosomes (Chen et al. 2017). Interestingly, it has been more difficult to reconstitute NAADP-activated ion fluxes with the conventional patch-clamp method than with the planar patch-clamp method or lipid bilayer technique. Indeed, this initially led to the assertion that TPCs were not NAADPregulated channels but regulated by phosphatidylinositol 3,5-bisphosphate (PtdIns3,5 $\mathrm{P}_{2}$ ), a specific endolysosomal inositol lipid (Wang et al. 2012). Indeed, no NAADP-activated currents were observed in this study, suggesting a failure to reconstitute NAADP-evoked $\mathrm{Ca}^{2+}$ release from lysosomes readily observed in intact cells. PtdIns3,5 $\mathrm{P}_{2}$ appears to be a general regulator of endolysosomal ion channels, in a similar way in which the plasma membrane lipid phosphatidylinositol 4,5-bisphosphate (PtdIns4,5 $\mathrm{P}_{2}$ ) regulates plasma membrane channels. However, even using the conventional patch-clamp technique, it has been possible to demonstrate NAADP-regulated channels in lysosomes (Jha et al. 2014). NAADP sensitivity of TPC2 channels expressed in lysosomes was more robust than for TPC2 mutants that are targeted to the plasma membrane. Indeed, NAADP-regulated plasma membrane currents were more readily observed with plasma membrane patches associated with organellar structures. It was suggested that this was caused by the greater association of TPCs with NAADP-binding proteins in the lysosome (Jha et al. 2014). In this study, it was also found that currents were 
A. Galione

inhibited rapidly by $\mathrm{Mg}^{2+}$ as well on a longer timescale by JNK/p38 kinases (Jha et al. 2014). A third method for patch-clamping organellar channels uses a hybrid biochemical organelle purification approach followed by a conventional patch-clamping approach with the aim of preserving the native membrane environment including associated accessory proteins (Shapovalov et al. 2017). Here, NAADP sensitivity to TPC2 is preserved with NAADP-evoked cation currents recorded.

These findings underscore the current opinion that NAADP binds to proteins that are distinct from the pore-forming subunits of the cation channels that they regulate (Ruas et al. 2015). Although TPCs are essential for NAADP-evoked $\mathrm{Ca}^{2+}$ release, they are unlikely to directly bind NAADP (Ruas et al. 2015). Photoaffinity labeling of NAADP-binding proteins in mammalian cell and sea urchin egg extracts indicate that these are separate from TPC subunits. In the case of sea urchin eggs, $40 / 45-\mathrm{kDa}$ binding proteins appear to associate with TPC subunits (Walseth et al. 2012a,b). Analysis of TPC interactomes are now being analyzed for possible candidates for the NAADP-binding site (Cang et al. 2013; Lin-Moshier et al. 2014; Krogsaeter et al. 2018).

The separation of the NAADP-binding site from the ion-conducting pore may explain the difficulty in reconstituting NAADP-mediated currents. In lipid bilayers, it may be that the relatively rare intact protein complexes are detected as single-channel recordings (Pitt et al. 2010). Because only large vesicles can be patched by the conventional patch-clamp method, it may be that the ratio of NAADPbinding proteins to TPCs is diluted during the chemical vesicular fusion processes required. The planar patch method allows for recordings from smaller vesicles, potentially underlying the more readily observed NAADP sensitivity. Another point is that we do not know how NAADP-binding proteins regulate TPCs or potentially other ion channels. It is possible that the protein could be inhibitory and that disinhibition occurs on NAADP binding. Because loss of this protein would have a similar effect, this could account for lack of NAADP effects in certain preparations. In addition, other factors including $\mathrm{Mg}^{2+}$ (Jha et al. 2014), $\mathrm{pH}$, $\mathrm{Ca}^{2+}$ (Pitt et al. 2010, 2014), mTOR (Cang et al. 2013; Ogunbayo et al. 2018), and other kinases (Jha et al. 2014; Lee et al. 2016) have been proposed to modulate the activity of TPCs.

TPCs are cation channels, which are quite selective for $\mathrm{Na}^{+}$ions under some conditions. Yet, varying degrees of permeability to $\mathrm{Ca}^{2+}$ have been reported (Morgan and Galione 2014; Ruas et al. 2015; Xu and Ren 2015; Pitt et al. 2016). A consensus is emerging that even a small $\mathrm{Ca}^{2+}$ permeability may be sufficient to generate $\mathrm{Ca}^{2+}$ microdomains, which may be adequate to trigger further $\mathrm{Ca}^{2+}$ release from the ER, as often observed (Patel et al. 2001; Calcraft et al. 2009; Ruas et al. 2010). It is unlikely that lysosomal $\mathrm{Na}^{+}$currents would indirectly trigger $\mathrm{Ca}^{2+}$ release from lysosomes because this would generally disfavor $\mathrm{Ca}^{2+}$ release in terms of lysosomal membrane potential changes (Morgan and $\mathrm{Ga}$ lione 2014).

Other channels have been proposed to be regulated by NAADP. Particularly prominent is RyR1, as proposed by Guse and colleagues for Jurkat $\mathrm{T}$ cells (recently reviewed in Guse and Diercks 2018). However, RyR1 is not required for NAADP-evoked $\mathrm{Ca}^{2+}$ release per se (Ruas et al. 2015), and a role for acidic stores and TPCs have been demonstrated by others in T-cell activation (Davis et al. 2012; Ali et al. 2016). However, it remains possible that NAADP-binding proteins may associate with multiple ion channels under certain conditions (Galione and Petersen 2005; Gerasimenko et al. 2015; Diercks et al. 2018).

\section{INTERACTIONS OF NAADP AND OTHER $\mathrm{Ca}^{2+}$ SIGNALING PATHWAYS}

NAADP-evoked $\mathrm{Ca}^{2+}$ release from lysosomes appears to be small and highly localized. Given the dynamic properties of these organelles, they are ideally suited to be targeted to the vicinity of $\mathrm{Ca}^{2+}$-regulated effectors. Three modes of NAADP-mediated $\mathrm{Ca}^{2+}$ signaling mechanisms have been highlighted (Fig. 5). 

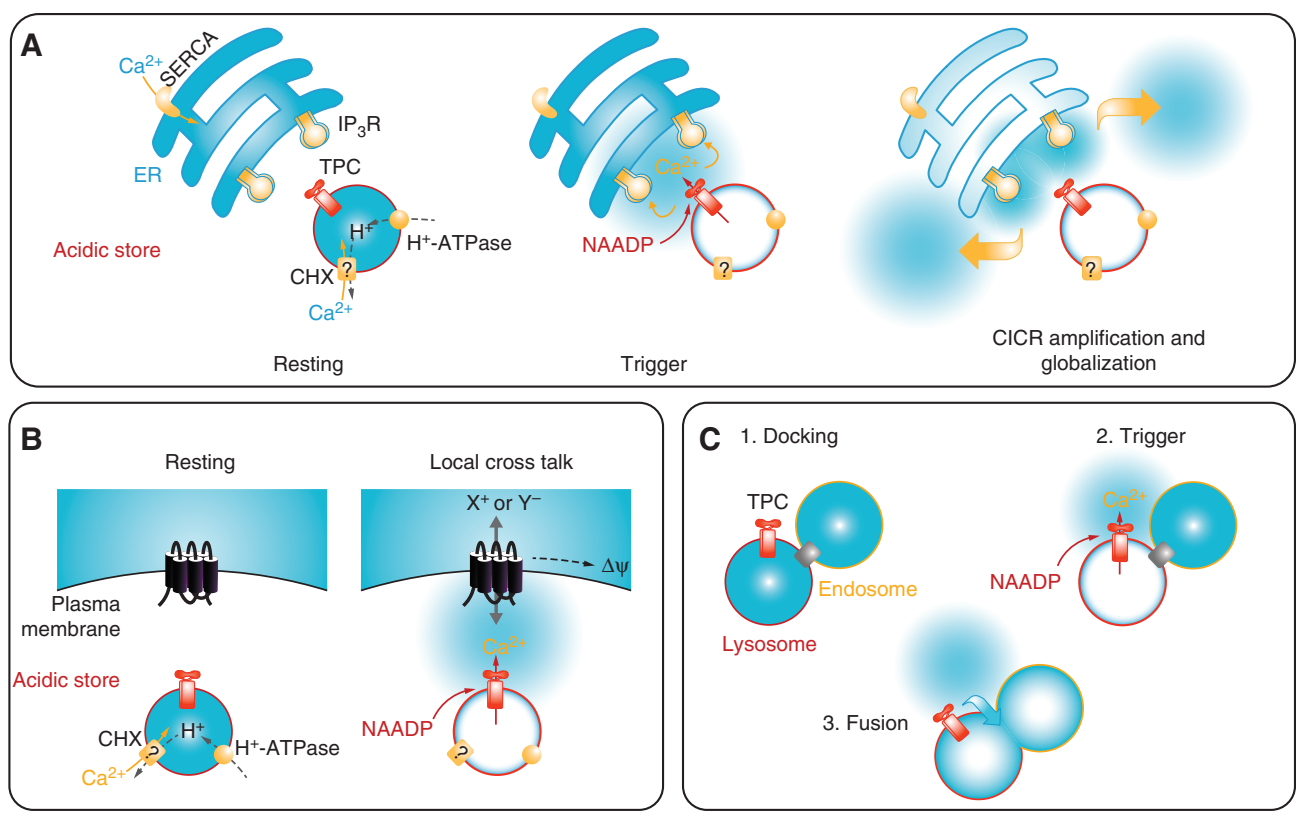

Figure 5. Three modes of nicotinic acid adenine nucleotide diphosphate (NAADP)-mediated $\mathrm{Ca}^{2+}$ signaling. (A) NAADP is a local trigger mechanism for detonating global $\mathrm{Ca}^{2+}$-induced $\mathrm{Ca}^{2+}$-release (CICR) responses from the endoplasmic reticulum (ER). (B) Local $\mathrm{Ca}^{2+}$ release by NAADP from acidic stores positioned under the plasma membrane may regulate membrane excitability (excitable cells) or ion fluxes (nonexcitable cells) by modulating $\mathrm{Ca}^{2+}$-activated plasma membrane channels. (C) NAADP regulates local cytoplasmic $\mathrm{Ca}^{2+} / \mathrm{pH}$ and luminal $\mathrm{Ca}^{2+} / \mathrm{pH}$ in endolysosomal compartments that may regulate vesicular fusion of late endosomes/ lysosomes.

\section{NAADP and Lysosomal-ER Interactions}

Organelle interactions in $\mathrm{Ca}^{2+}$-signaling is not a new concept. For example, $\mathrm{Ca}^{2+}$ microdomains may arise around sites of $\mathrm{ER} \mathrm{Ca}^{2+}$ release and neighboring organelles may be profoundly affected physiologically. Indeed ER-mitochondrial interactions have been well studied in the context of $\mathrm{IP}_{3} \mathrm{R}$ and $\mathrm{RyR}$-mediated $\mathrm{Ca}^{2+}$ release (Rizzuto et al. 1998; Csordás et al. 2001), which impacts on mitochondrial metabolism and apoptotic pathways. Membrane contact sites have been demonstrated between a number of organelles and may be important foci for lipid and molecular transfer as well as $\mathrm{Ca}^{2+}$. The protein mitofusin 2 has been proposed to regulate ER and mitochondrial membrane tethering, although there are opposing views as to whether it promotes (de Brito and Scorrano 2008), or inhibits (Filadi et al. 2015), such interactions. A number of protein candidates have been sug- gested to play such a role for endolysosomal-ER interactions (Kilpatrick et al. 2013; Lam and Galione 2013; Morgan et al. 2013; Penny et al. 2015; Atakpa et al. 2018), in which they may facilitate both lipid and $\mathrm{Ca}^{2+}$ exchange at membrane contact sites.

NAADP-evoked $\mathrm{Ca}^{2+}$ release and its effects on $\mathrm{Ca}^{2+}$-release channels on the ER/sarcoplasmic reticulum (SR) was first noted in pancreatic acinar cells (Cancela et al. 1999). This phenomenon, whereby a localized microdomain of $\mathrm{Ca}^{2+}$ release from acidic stores triggers a larger release from the ER, is widely observed in both the sea urchin egg and in many types of mammalian cell, and is one of the fundamental principles of NAADP-mediated $\mathrm{Ca}^{2+}$ signaling. The trigger hypothesis was formulated by the finding that NAADP-evoked responses in pancreatic acinar cells could be blocked by either heparin or ryanodine, as well as self-inactivation of the NAADP receptor with NAADP itself (Cancela 
et al. 1999). This was visualized in the larger sea urchin egg by detailed imaging studies (Churchill and Galione 2000, 2001a,b). NAADP was found to act as a local messenger to form $\mathrm{Ca}^{2+}$ gradients across the cell based on NAADP diffusion. These gradients could be amplified and globalized by CICR through the recruitment of $\mathrm{IP}_{3} \mathrm{R}$ and RyR-dependent mechanisms on the ER. Because of the distinct self-inactivation properties of NAADP receptors, subsequent NAADP-evoked $\mathrm{Ca}^{2+}$ signaling patterns only occur in regions of the cell where NAADP had not previously evoked a response (Churchill and Galione 2001b). This effect lasts for many minutes, representing a basic type of spatiotemporal memory in terms of the generation of $\mathrm{Ca}^{2+}$ signal patterning. As well as spatial complexities, NAADP could produce temporal patterns in $\mathrm{Ca}^{2+}$ signals by the uptake of $\mathrm{Ca}^{2+}$ released from NAADP-sensitive stores into the ER to produce a series of $\mathrm{Ca}^{2+}$ spikes dependent on $\mathrm{IP}_{3} \mathrm{R}$ and RyRs (Churchill and Galione 2001b). Bidirectional $\mathrm{Ca}^{2+}$ transfer between $\mathrm{ER}$ and acidic stores has also been demonstrated in the sea urchin egg (Morgan et al. 2013).

In pulmonary vascular smooth muscle cells, NAADP and the vasoactive hormone, endothelin-1, evoke a localized $\mathrm{Ca}^{2+}$ release from lysosomes at lysosomal-SR junctions, which is then amplified and globalized by a mechanism dependent on recruitment of RyRs on the SR (Kinnear et al. 2004, 2008). Similar results have been reported in coronary smooth myocytes (Zhang et al. 2006), and also implicated for early Fas signaling processes that eventually lead to apoptosis (Zhang et al. 2010).

In Jurkat or native $\mathrm{T}$ cells, NAADP triggers $\mathrm{Ca}^{2+}$ release from acidic stores, which can be amplified by RyRs and $\mathrm{IP}_{3} \mathrm{Rs}$ (Davis et al. 2012; Ali et al. 2016), but as mentioned above, NAADP has also been proposed to activate RyR1 on the ER directly (Dammermann and Guse 2005; Dammermann et al. 2009). A role for RyR as the direct target for NAADP has also been proposed in pancreatic acinar cell ER/nuclear membranes (Gerasimenko et al. 2015), although other evidence points to direct activation of acidic stores (Yamasaki et al. 2004; Menteyne et al. 2006) followed by amplification by CICR
Such discrepancies are not surprising given the small release of $\mathrm{Ca}^{2+}$ released by lysosomes that TPC studies have revealed (Calcraft et al. 2009; Ruas et al. 2010), with amplification by ER mechanisms providing much larger $\mathrm{Ca}^{2+}$ signals. Thus, in small cells, dissection of contributory $\mathrm{Ca}^{2+}$-release mechanisms can prove difficult (Galione and Petersen 2005), but the demonstration of RyRs $/ \mathrm{IP}_{3} \mathrm{Rs}$ at ER-lysosomal contact sites may prove crucial (Kinnear et al. 2004; Galione et al. 2009; Aston et al. 2017; Atakpa et al. 2018; Diercks et al. 2018).

\section{Modulation of Plasma Membrane Excitability}

Besides their involvement in organelle communication, NAADP and TPCs appear to play an important role in regulating ion fluxes across the plasma membrane and hence also excitability of excitable cells. NAADP has been shown to stimulate $\mathrm{Ca}^{2+}$ influx across the plasma membrane of several cell types including starfish oocytes (Moccia et al. 2003, 2006) and sea urchin eggs (Churchill et al. 2003) in which it, uniquely among $\mathrm{Ca}^{2+}$-mobilizing messengers, mediates the polyspermic blocking "cortical flash" and Jurkat T cells (Langhorst et al. 2004). What is not clear is whether NAADP directly activates plasma membrane channels or whether NAADP first releases $\mathrm{Ca}^{2+}$ from intracellular stores, which then leads to activation of plasma membrane conductances. Indeed, at present, there is no evidence for TPC localization at the plasma membrane.

However, local NAADP-evoked $\mathrm{Ca}^{2+}$ release from acidic stores in the vicinity of the plasma membrane has been shown in several cell types to open $\mathrm{Ca}^{2+}$-activated ion channels. This was first shown in nonexcitable pancreatic acinar cells, in which activation of such channels is likely to contribute to fluid secretion (Cancela et al. 1999). However, this may be a major mechanism in excitable cells. In pancreatic $\beta$ cells, NAADP also evokes $\mathrm{Ca}^{2+}$-dependent currents, which may contribute to glucose-mediated depolarization of the cells during stimulus-secretion coupling (Naylor et al. 2009), and which are absent in cells derived from $T p c 2^{-/-}$mice (Cal- 
craft et al. 2009). In neurones from the rat medulla oblongata (Brailoiu et al. 2009b), NAADP also depolarizes cells through a mechanism dependent on $\mathrm{Ca}^{2+}$ release from acidic stores.

Recently, NAADP has been shown to modulate plasma membrane $\mathrm{K}^{+}$channels in mouse hippocampal slices and to mediate the effects of mGluR1 activation. A role for the NAADP/TPC axis was demonstrated to be important in synaptic plasticity and remarkably in $T p c 1^{-/-}$or $T p c 2^{-1-}$ neurones, protocols that normally induce long-term potentiation are now abolished and a long-term depression may now be manifested (Foster et al. 2018).

\section{NAADP and Its Receptors in Endolysosomal Physiology}

NAADP may be unique among $\mathrm{Ca}^{2+}$-mobilizing messengers in that in contrast to $\mathrm{IP}_{3}$ or $\mathrm{CADPR}$, it may in most cases directly evoke $\mathrm{Ca}^{2+}$ release from the endolysosomal system. NAADP-regulated TPCs are a new group of channels that are targeted to the endolysosomal system, along

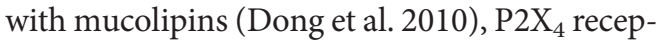
tors (Qureshi et al. 2007; Huang et al. 2014), and TRPM2 (Lange et al. 2009), all of which are likely to influence the ionic environment in acidic organelles. Interestingly, TRPM2 have also been proposed as NAADP receptors (Beck et al. 2006); however, they have much lower affinities for NAADP, in the high $\mu \mathrm{M}$ range, and $2^{\prime}$-deoxy-ADPR has recently been proposed as the major endogenous agonist (Fliegert et al. $2017,2018)$. TRPM 2 could provide local $\mathrm{Ca}^{2+}$ signals, which may directly impinge on the pleiotropic roles of the endolysosomal system including lysosomal biogenesis, vesicular trafficking and transport, and autophagy. Both local and luminal $\mathrm{Ca}^{2+}$ is important for many of these processes, including homotypic fusion processes of endosomes and heterotypic fusions of late endosomes with lysosomes, as well as condensation of luminal contents (Piper and Luzio 2004; Luzio et al. 2007), and release of $\mathrm{Ca}^{2+}$ from endolysosomal stores is thought to be a crucial regulatory mechanism. Overexpression of TPCs in HEK293 causes profound changes in trafficking, lysosomal size, and distribution as observed in certain lysosomal storage diseases (Ruas et al. 2010). These effects can be ameliorated by treatment with the NAADP antagonist, Ned-19. These data are suggestive for a major role of NAADP and TPC proteins in the regulation of luminal $\mathrm{Ca}^{2+}, \mathrm{Ca}^{2+}$ release, and local $\mathrm{Ca}^{2+}$ signaling in endolysosomal physiology, and are thus likely to be key regulators of trafficking (Ruas et al. 2010; Grimm et al. 2014; LinMoshier et al. 2014; Kilpatrick et al. 2017), autophagy (Pereira et al. 2011, 2017; Lin et al. 2015; García-Rúa et al. 2016; Rah et al. 2017; Ogunbayo et al. 2018; Sun and Yue 2018), and other functions of these organelles. In addition, recent findings suggest a role for NAADP and TPCmediated endolysosomal $\mathrm{Ca}^{2+}$ fluxes in viral infections (Sakurai et al. 2015; Gunaratne et al. 2018 b), prompting the search for small molecule inhibitors of this pathway as novel antiviral agents (Gunaratne et al. 2018a; Penny et al. 2018).

\section{CONCLUSIONS: WHY HAVE MULTIPLE MESSENGERS FOR $\mathrm{Ca}^{2+}$ RELEASE?}

Over the last decade or so, NAADP has joined $\mathrm{IP}_{3}$ and $\mathrm{CADPR}$ as a major $\mathrm{Ca}^{2+}$-mobilizing messenger. A major question in $\mathrm{Ca}^{2+}$ signaling research is how ubiquitous $\mathrm{Ca}^{2+}$ signals can encode specificity, and a general view is that the complex spatial and temporal patterns of $\mathrm{Ca}^{2+}$ signals widely observed in cells, are key to understanding this problem. The coordination of $\mathrm{Ca}^{2+}$ signals by multiple messengers acting at differentially distributed target $\mathrm{Ca}^{2+}$-release channels with different properties, offers one possible solution. For example, NAADP-evoked $\mathrm{Ca}^{2+}$ release leads to neuronal cell differentiation (Brailoiu et al. 2006), whereas cADPR-mediated $\mathrm{Ca}^{2+}$ release leads to cell proliferation, but delays differentiation (Yue et al. 2009). On the other hand, activation of certain cell surface receptors may produce different combinations of messengers, which are required to mimic the specific $\mathrm{Ca}^{2+}$ signaling patterns evoked by the particular receptor agonist (Cancela et al. 2002; Yamasaki et al. 2005), thus increasing the repertoire of cellular responses mediated by $\mathrm{Ca}^{2+}$. 
The emerging view that NAADP directly targets acidic stores rather than the $\mathrm{ER}$ is an important new principle in $\mathrm{Ca}^{2+}$ signaling and cellular homeostasis, and allows NAADP to evoke distinct $\mathrm{Ca}^{2+}$ signals from those mobilizing the ER. This was initially proposed on the basis of pharmacological studies but the identification of endolysosomal TPC proteins as major targets for NAADP, has begun to cement this hypothesis in molecular terms. Three major consequences of NAADP-evoked $\mathrm{Ca}^{2+}$ release have been identified. The unifying principle is that NAADP by mobilizing acidic stores leads to localized $\mathrm{Ca}^{2+}$ signals that may trigger key cellular responses. Depending on the subcellular localization of these stores, there are fundamentally different consequences of NAADP-mediated $\mathrm{Ca}^{2+}$ release. First, for stores proximal to the plasma membrane, $\mathrm{Ca}^{2+}$-activated plasma channels may be activated. Such ion fluxes produced in nonexcitable cells may, for example, be important in fluid secretion. In excitable cells, depolarization and changes in membrane excitability may result. Second, for stores opposed to the ER, NAADP-evoked $\mathrm{Ca}^{2+}$ release from acidic stores may trigger globalized $\mathrm{Ca}^{2+}$ responses by activating $\mathrm{IP}_{3} \mathrm{Rs}$ or RyRs by CICR. The third major aspect is the regulation of luminal $\mathrm{Ca}^{2+}$ and $\mathrm{pH}$ homeostasis, as well as local peri-endolysosomal $\mathrm{Ca}^{2+}$ signals. These may have a major impact on the many roles of these organelles in key cellular processes that they control, including vesicular trafficking, autophagy, apoptosis, autolysis as well as their role in fighting infection. Cellular stimuli may be selectively coupled to NAADP signaling pathways, or as is commonly observed, to multiple messenger pathways, either providing distinct patterns of $\mathrm{Ca}^{2+}$ signals leading to specific responses.

The establishment of a role of the endolysosomal system in $\mathrm{Ca}^{2+}$ signaling, the identification of specific $\mathrm{Ca}^{2+}$-release channels of acidic organelles as the targets for NAADP, open up new possibilities for a better understanding of the mechanisms of cellular $\mathrm{Ca}^{2+}$ signaling and how this goes awry in disease, and its control and pharmacological manipulation. However, the identity of NAADP-binding proteins are urgently awaited.

\section{ACKNOWLEDGMENTS}

A.G. is a Wellcome Trust Senior Investigator and a Principal Investigator of the British Heart Foundation Centre of Research Excellence at the University of Oxford. I thank Dr. Anthony Morgan for helpful discussion and help with preparing the figures.

\section{REFERENCES}

Aarhus R, Dickey DM, Graeff RM, Gee KR, Walseth TF, Lee HC. 1996. Activation and inactivation of $\mathrm{Ca}^{2+}$ release by $\mathrm{NAADP}^{+}$. J Biol Chem 271: 8513-8516. doi:10.1074/jbc .271 .15 .8513

Aley PK, Noh HJ, Gao X, Tica AA, Brailoiu E, Churchill GC. 2010. A functional role for nicotinic acid adenine dinucleotide phosphate in oxytocin-mediated contraction of uterine smooth muscle from rat. J Pharmacol Exp Ther 333: 726-735. doi:10.1124/jpet.110.165837

Ali RA, Zhelay T, Trabbic CJ, Walseth TF, Slama JT, Giovannucci DR, Wall KA. 2014. Activity of nicotinic acid substituted nicotinic acid adenine dinucleotide phosphate (NAADP) analogs in a human cell line: Difference in specificity between human and sea urchin NAADP receptors. Cell Calcium 55: 93-103. doi:10.1016/j.ceca.2013.12 .004

Ali RA, Camick C, Wiles K, Walseth TF, Slama JT, Bhattacharya S, Giovannucci DR, Wall KA. 2016. Nicotinic acid adenine dinucleotide phosphate plays a critical role in naive and effector murine $\mathrm{T}$ cells but not natural regulatory T cells. J Biol Chem 291: 4503-4522. doi:10.1074/jbc .M115.681833

Aston D, Capel RA, Ford KL, Christian HC, Mirams GR, Rog-Zielinska EA, Kohl P, Galione A, Burton RA, Terrar DA. 2017. High resolution structural evidence suggests the sarcoplasmic reticulum forms microdomains with acidic stores (lysosomes) in the heart. Sci Rep 7: 40620. doi:10.1038/srep40620

Atakpa P, Thillaiappan NB, Mataragka S, Prole DL, Taylor CW. 2018. $\mathrm{IP}_{3}$ receptors preferentially associate with ERlysosome contact sites and selectively deliver $\mathrm{Ca}^{2+}$ to lysosomes. Cell Rep 25: 3180-3193.e3187. doi:10.1016/j .celrep.2018.11.064

Atakpa P, van Marrewijk LM, Apta-Smith M, Chakraborty S, Taylor CW. 2019. GPN does not release lysosomal $\mathrm{Ca}^{2+}$, but evokes ER $\mathrm{Ca}^{2+}$ release by increasing cytosolic $\mathrm{pH}$ independent of cathepsin C. J Cell Sci 132: jcs223883. doi:10.1242/jcs.223883

Barceló-Torns M, Lewis AM, Gubern A, Barneda D, BloorYoung D, Picatoste F, Churchill GC, Claro E, Masgrau R. 2011. NAADP mediates ATP-induced $\mathrm{Ca}^{2+}$ signals in astrocytes. FEBS Lett 585: 2300-2306. doi:10.1016/j .febslet.2011.05.062

Beck A, Kolisek M, Bagley LA, Fleig A, Penner R. 2006. Nicotinic acid adenine dinucleotide phosphate and cyclic ADP-ribose regulate TRPM2 channels in T lymphocytes. FASEB J 20: 962-964. doi:10.1096/fj.05-5538fje

Berg I, Potter BV, Mayr GW, Guse AH. 2000. Nicotinic acid adenine dinucleotide phosphate $\left(\mathrm{NAADP}^{+}\right)$is an essen- 
tial regulator of T-lymphocyte $\mathrm{Ca}^{2+}$-signaling. J Cell Biol 150: 581-588. doi:10.1083/jcb.150.3.581

Berridge MJ, Bootman MD, Lipp P. 1998. Calcium-A life and death signal. Nature 395: 645-648. doi:10.1038/ 27094

Berridge G, Cramer R, Galione A, Patel S. 2002a. Metabolism of the novel $\mathrm{Ca}^{2+}$-mobilizing messenger nicotinic acidadenine dinucleotide phosphate via a $2^{\prime}$-specific $\mathrm{Ca}^{2+}$-dependent phosphatase. Biochem J 365: 295-301. doi:10 $.1042 /$ bj20020180

Berridge G, Dickinson G, Parrington J, Galione A, Patel S. $2002 \mathrm{~b}$. Solubilization of receptors for the novel $\mathrm{Ca}^{2+}-\mathrm{mo}$ bilizing messenger, nicotinic acid adenine dinucleotide phosphate. J Biol Chem 277: 43717-43723. doi:10.1074/ jbc.M203224200

Berridge MJ, Bootman MD, Roderick HL. 2003. Calcium signalling: Dynamics, homeostasis and remodelling. Nat Rev Mol Cell Biol 4: 517-529. doi:10.1038/nrm1155

Billington RA, Genazzani AA. 2007. PPADS is a reversible competitive antagonist of the NAADP receptor. Cell Calcium 41: 505-511. doi:10.1016/j.ceca.2006.10.002

Bootman M, Berridge M, Roderick H. 2002. Calcium signalling: More messengers, more channels, more complexity. Curr Biol 12: R563. doi:10.1016/S0960-9822(02)01055-2

Brailoiu E, Churamani D, Pandey V, Brailoiu GC, Tuluc F, Patel S, Dun NJ. 2006. Messenger-specific role for nicotinic acid adenine dinucleotide phosphate in neuronal differentiation. J Biol Chem 281: 15923-15928. doi:10 $.1074 /$ jbc.M602249200

Brailoiu E, Churamani D, Cai X, Schrlau MG, Brailoiu GC, Gao X, Hooper R, Boulware MJ, Dun NJ, Marchant JS, et al. 2009a. Essential requirement for two-pore channel 1 in NAADP-mediated calcium signaling. J Cell Biol 186: 201-209. doi:10.1083/jcb.200904073

Brailoiu GC, Brailoiu E, Parkesh R, Galione A, Churchill GC, Patel S, Dun NJ. 2009b. NAADP-mediated channel "chatter" in neurons of the rat medulla oblongata. Biochem J 419: 91-99. doi:10.1042/BJ20081138

Brailoiu E, Hooper R, Cai X, Brailoiu GC, Keebler MV, Dun NJ, Marchant JS, Patel S. 2010a. An ancestral deuterostome family of two-pore channels mediates nicotinic acid adenine dinucleotide phosphate-dependent calcium release from acidic organelles. J Biol Chem 285: 28972901. doi:10.1074/jbc.C109.081943

Brailoiu GC, Gurzu B, Gao X, Parkesh R, Aley PK, Trifa DI, Galione A, Dun NJ, Madesh M, Patel S, et al. 2010b. Acidic NAADP-sensitive calcium stores in the endothelium: Agonist-specific recruitment and role in regulating blood pressure. J Biol Chem 285: 37133-37137. doi:10 $.1074 /$ jbc.C110.169763

Brailoiu GC, Oprea TI, Zhao P, Abood ME, Brailoiu E. 2011. Intracellular cannabinoid type $1\left(\mathrm{CB}_{1}\right)$ receptors are activated by anandamide. J Biol Chem 286: 29166-29174. doi:10.1074/jbc.M110.217463

Cai X, Patel S. 2010. Degeneration of an intracellular ion channel in the primate lineage by relaxation of selective constraints. Mol Biol Evol 27: 2352-2359. doi:10.1093/ molbev/msq122

Calcraft PJ, Ruas M, Pan Z, Cheng X, Arredouani A, Hao X, Tang J, Rietdorf K, Teboul L, Chuang KT, et al. 2009. NAADP mobilizes calcium from acidic organelles through two-pore channels. Nature 459: 596-600. doi:10.1038/nature08030

Cancela JM, Churchill GC, Galione A. 1999. Coordination of agonist-induced $\mathrm{Ca}^{2+}$-signalling patterns by NAADP in pancreatic acinar cells. Nature 398: 74-76. doi:10.1038/ 18032

Cancela JM, Van Coppenolle F, Galione A, Tepikin AV, Petersen OH. 2002. Transformation of local $\mathrm{Ca}^{2+}$ spikes to global $\mathrm{Ca}^{2+}$ transients: The combinatorial roles of multiple $\mathrm{Ca}^{2+}$ releasing messengers. EMBO J 21: 909-919. doi:10.1093/emboj/21.5.909

Cang C, Zhou Y, Navarro B, Seo YJ, Aranda K, Shi L, Battaglia-Hsu S, Nissim I, Clapham DE, Ren D. 2013. mTOR regulates lysosomal ATP-sensitive two-pore $\mathrm{Na}^{+}$channels to adapt to metabolic state. Cell 152: 778-790. doi:10.1016/j.cell.2013.01.023

Capel RA, Bolton EL, Lin WK, Aston D, Wang Y, Liu W, Wang X, Burton RA, Bloor-Young D, Shade KT, et al. 2015. Two-pore channels (TPC2s) and nicotinic acid adenine dinucleotide phosphate (NAADP) at lysosomal-sarcoplasmic reticular junctions contribute to acute and chronic $\beta$-adrenoceptor signaling in the heart. $J$ Biol Chem 290: 30087-30098. doi:10.1074/jbc.M115 .684076

Cavalli AL, O'Brien NW, Barlow SB, Betto R, Glembotski CC, Palade PT, Sabbadini RA. 2003. Expression and functional characterization of SCaMPER: A sphingolipidmodulated calcium channel of cardiomyocytes. Am J Physiol Cell Physiol 284: C780-C790. doi:10.1152/ajp cell. 00382.2002

Chen CC, Butz ES, Chao YK, Grishchuk Y, Becker L, Heller S, Slaugenhaupt SA, Biel M, Wahl-Schott C, Grimm C. 2017. Small molecules for early endosome-specific patch clamping. Cell Chem Biol 24: 907-916.e904. doi:10.1016/j .chembiol.2017.05.025

Chini EN, Beers KW, Dousa TP. 1995. Nicotinate adenine dinucleotide phosphate (NAADP) triggers a specific calcium release system in sea urchin eggs. J Biol Chem 270: 3216-3223. doi:10.1074/jbc.270.7.3216

Christensen KA, Myers JT, Swanson JA. 2002. pH-dependent regulation of lysosomal calcium in macrophages. $J$ Cell Sci 115: 599-607.

Churamani D, Carrey EA, Dickinson GD, Patel S. 2004. Determination of cellular nicotinic acid-adenine dinucleotide phosphate (NAADP) levels. Biochem J 380: 449-454. doi:10.1042/bj20031754

Churchill GC, Galione A. 2000. Spatial control of $\mathrm{Ca}^{2+}$ signaling by nicotinic acid adenine dinucleotide phosphate diffusion and gradients. J Biol Chem 275: 38687-38692. doi:10.1074/jbc.M005827200

Churchill GC, Galione A. 2001a. NAADP induces $\mathrm{Ca}^{2+}$ oscillations via a two-pool mechanism by priming $\mathrm{IP}_{3}-$ and cADPR-sensitive $\mathrm{Ca}^{2+}$ stores. EMBO J 20: 2666-2671. doi:10.1093/emboj/20.11.2666

Churchill GC, Galione A. 2001b. Prolonged inactivation of nicotinic acid adenine dinucleotide phosphate-induced $\mathrm{Ca}^{2+}$ release mediates a spatiotemporal $\mathrm{Ca}^{2+}$ memory. $J$ Biol Chem 276: 11223-11225. doi:10.1074/jbc.M00 9335200

Churchill GC, Okada Y, Thomas JM, Genazzani AA, Patel S, Galione A. 2002. NAADP mobilizes $\mathrm{Ca}^{2+}$ from reserve 
granules, lysosome-related organelles, in sea urchin eggs. Cell 111: 703-708. doi:10.1016/S0092-8674(02)01082-6

Churchill GC, O’Neill JS, Masgrau R, Patel S, Thomas JM, Genazzani AA, Galione A. 2003. Sperm deliver a new second messenger: NAADP. Curr Biol 13: 125-128. doi:10.1016/S0960-9822(03)00002-2

Clapham DE. 2007. Calcium signaling. Cell 131: 1047-1058. doi:10.1016/j.cell.2007.11.028

Clapper DL, Lee HC. 1985. Inositol trisphosphate induces calcium release from nonmitochondrial stores in sea urchin egg homogenates. J Biol Chem 260: 13947-13954.

Clapper DL, Walseth TF, Dargie PJ, Lee HC. 1987. Pyridine nucleotide metabolites stimulate calcium release from sea urchin egg microsomes desensitized to inositol trisphosphate. J Biol Chem 262: 9561-9568.

Cosker F, Cheviron N, Yamasaki M, Menteyne A, Lund FE, Moutin MJ, Galione A, Cancela JM. 2010. The ecto-enzyme $\mathrm{CD} 38$ is a nicotinic acid adenine dinucleotide phosphate (NAADP) synthase that couples receptor activation to $\mathrm{Ca}^{2+}$ mobilization from lysosomes in pancreatic acinar cells. J Biol Chem 285: 38251-38259. doi:10.1074/jbc .M110.125864

Csordás G, Thomas AP, Hajnoczky G. 2001. Calcium signal transmission between ryanodine receptors and mitochondria in cardiac muscle. Trends Cardiovasc Med 11: 269-275. doi:10.1016/S1050-1738(01)00123-2

Dammermann W, Guse AH. 2005. Functional ryanodine receptor expression is required for NAADP-mediated local $\mathrm{Ca}^{2+}$ signaling in T-lymphocytes. J Biol Chem 280: 21394-21399. doi:10.1074/jbc.M413085200

Dammermann W, Zhang B, Nebel M, Cordiglieri C, Odoardi F, Kirchberger T, Kawakami N, Dowden J, Schmid F, Dornmair K, et al. 2009. NAADP-mediated $\mathrm{Ca}^{2+}$ signaling via type 1 ryanodine receptor in $\mathrm{T}$ cells revealed by a synthetic NAADP antagonist. Proc Natl Acad Sci 106: 10678-10683. doi:10.1073/pnas .0809997106

Davis LC, Morgan AJ, Ruas M, Wong JL, Graeff RM, Poustka AJ, Lee HC, Wessel GM, Parrington J, Galione A. 2008. $\mathrm{Ca}^{2+}$ signaling occurs via second messenger release from intraorganelle synthesis sites. Curr Biol 18: 1612-1618. doi:10.1016/j.cub.2008.09.024

Davis LC, Morgan AJ, Chen JL, Snead CM, Bloor-Young D, Shenderov E, Stanton-Humphreys MN, Conway SJ, Churchill GC, Parrington J, et al. 2012. NAADP activates two-pore channels on T cell cytolytic granules to stimulate exocytosis and killing. Curr Biol 22: 2331-2337. doi:10.1016/j.cub.2012.10.035

de Brito OM, Scorrano L. 2008. Mitofusin 2 tethers endoplasmic reticulum to mitochondria. Nature 456: 605-610. doi:10.1038/nature07534

Dickey DM, Aarhus R, Walseth TF, Lee HC. 1998. ThioNADP is not an antagonist of NAADP. Cell Biochem Biophys 28: 63-73. doi:10.1007/BF02738310

Dickinson GD, Patel S. 2003. Modulation of NAADP (nicotinic acid-adenine dinucleotide phosphate) receptors by $\mathrm{K}^{+}$ions: Evidence for multiple NAADP receptor conformations. Biochem J 375: 805-812. doi:10.1042/ BJ20030672

Dickinson GD, Churchill GC, Brailoiu E, Patel S. 2010. Deviant nicotinic acid adenine dinucleotide phosphate (NAADP)-mediated $\mathrm{Ca}^{2+}$ signaling upon lysosome pro- liferation. J Biol Chem 285: 13321-13325. doi:10.1074/jbc .C110.112573

Diercks BP, Werner R, Weidemüller P, Czarniak F, Hernandez L, Lehmann C, Rosche A, Krüger A, Kaufmann U, Vaeth M, et al. 2018. ORAI1, STIM1/2, and RYR1 shape subsecond $\mathrm{Ca}^{2+}$ microdomains upon $\mathrm{T}$ cell activation. $\mathrm{Sci}$ Signal 11: eaat0358. doi:10.1126/scisignal.aat0358

Dong XP, Wang X, Xu H. 2010. TRP channels of intracellular membranes. J Neurochem 113: 313-328. doi:10.1111/j $.1471-4159.2010 .06626 . x$

Dowden J, Berridge G, Moreau C, Yamasaki M, Churchill GC, Potter BV, Galione A. 2006. Cell-permeant smallmolecule modulators of NAADP-mediated $\mathrm{Ca}^{2+}$ release. Chem Biol 13: 659-665. doi:10.1016/j.chembiol.2006.05 .005

Ehrlich BE, Watras J. 1988. Inositol 1,4,5-trisphosphate activates a channel from smooth muscle sarcoplasmic reticulum. Nature 336: 583-586. doi:10.1038/336583a0

Epel D. 1964. A primary metabolic change of fertilization: Interconversion of pyridine nucleotides. Biochem Biophys Res Commun 17: 62-68. doi:10.1016/0006-291X(64)90 301-8

Esposito B, Gambara G, Lewis AM, Palombi F, D’Alessio A, Taylor LX, Genazzani AA, Ziparo E, Galione A, Churchill $\mathrm{GC}$, et al. 2011. NAADP links histamine $\mathrm{H}_{1}$ receptors to secretion of von Willebrand factor in human endothelial cells. Blood 117: 4968-4977. doi:10.1182/blood-2010-02266338

Fang C, Li T, Li Y, Xu GJ, Deng QW, Chen YJ, Hou YN, Lee HC, Zhao YJ. 2018. CD38 produces nicotinic acid adenosine dinucleotide phosphate in the lysosome. J Biol Chem 293: 8151-8160. doi:10.1074/jbc.RA118.002113

Ferrero E, Lo Buono N, Horenstein AL, Funaro A, Malavasi F. 2014. The ADP-ribosyl cyclases-The current evolutionary state of the ARCs. Front Biosci (Landmark Ed) 19: 986-1002. doi:10.2741/4262

Filadi R, Greotti E, Turacchio G, Luini A, Pozzan T, Pizzo P. 2015. Mitofusin 2 ablation increases endoplasmic reticulum-mitochondria coupling. Proc Natl Acad Sci 112: E2174-E2181. doi:10.1073/pnas.1504880112

Fliegert R, Bauche A, Wolf Perez AM, Watt JM, Rozewitz MD, Winzer R, Janus M, Gu F, Rosche A, Harneit A, et al. 2017. $2^{\prime}$-Deoxyadenosine $5^{\prime}$-diphosphoribose is an endogenous TRPM2 superagonist. Nat Chem Biol 13: 1036-1044. doi:10.1038/nchembio.2415

Fliegert R, Hölzer HT, Guse AH. 2018. TRPM2 activation: Paradigm shifted? Cell Calcium 76: 132-134. doi:10.1016/ j.ceca.2018.11.001

Foster WJ, Taylor HBC, Padamsey Z, Jeans AF, Galione A, Emptage NJ. 2018. Hippocampal mGluR1-dependent long-term potentiation requires NAADP-mediated acidic store $\mathrm{Ca}^{2+}$ signaling. Sci Signal 11: eaat9093. doi:10.1126/ scisignal.aat 9093

Furuichi T, Cunningham KW, Muto S. 2001. A putative two pore channel AtTPC1 mediates $\mathrm{Ca}^{2+}$ flux in Arabidopsis leaf cells. Plant Cell Physiol 42: 900-905. doi:10.1093/pcp/ pce 145

Galione A. 2006. NAADP, a new intracellular messenger that mobilizes $\mathrm{Ca}^{2+}$ from acidic stores. Biochem Soc Trans 34: 922-926. doi:10.1042/BST0340922 
Galione A, Petersen OH. 2005. The NAADP receptor: New receptors or new regulation? Mol Interv 5: 73-79. doi:10 $.1124 / \mathrm{mi} .5 .2 .4$

Galione A, Evans AM, Ma J, Parrington J, Arredouani A, Cheng X, Zhu MX. 2009. The acid test: The discovery of two-pore channels (TPCs) as NAADP-gated endolysosomal Ca ${ }^{2+}$ release channels. Pflugers Arch 458: 869-876. doi:10.1007/s00424-009-0682-y

Gambara G, Billington RA, Debidda M, D’Alessio A, Palombi F, Ziparo E, Genazzani AA, Filippini A. 2008 NAADP-induced $\mathrm{Ca}^{2+}$ signaling in response to endothelin is via the receptor subtype $B$ and requires the integrity of lipid rafts/caveolae. J Cell Physiol 216: 396-404. doi:10 $.1002 /$ jcp. 21407

García-Rúa V, Feijóo-Bandín S, Rodríguez-Penas D, Mosquera-Leal A, Abu-Assi E, Beiras A, María Seoane L, Lea P, Parrington J, Portolés M, et al. 2016. Endolysosomal two-pore channels regulate autophagy in cardiomyocytes. J Physiol 594: 3061-3077. doi:10.1113/JP271332

Garrity AG, Wang W, Collier CM, Levey SA, Gao Q, Xu H. 2016. The endoplasmic reticulum, not the $\mathrm{pH}$ gradient, drives calcium refilling of lysosomes. eLife 5: e15887. doi:10.7554/eLife.15887

Gasser A, Bruhn S, Guse AH. 2006. Second messenger function of nicotinic acid adenine dinucleotide phosphate revealed by an improved enzymatic cycling assay. $J$ Biol Chem 281: 16906-16913. doi:10.1074/jbc.M601347200

Genazzani AA, Galione A. 1996. Nicotinic acid-adenine dinucleotide phosphate mobilizes $\mathrm{Ca}^{2+}$ from a thapsigargin-insensitive pool. Biochem J 315: 721-725. doi:10 $.1042 / \mathrm{bj} 3150721$

Genazzani AA, Empson RM, Galione A. 1996. Unique inactivation properties of NAADP-sensitive $\mathrm{Ca}^{2+}$ release. $J$ Biol Chem 271: 11599-11602. doi:10.1074/jbc.271.20 .11599

Genazzani AA, Mezna M, Dickey DM, Michelangeli F, Walseth TF, Galione A. 1997a. Pharmacological properties of the $\mathrm{Ca}^{2+}$-release mechanism sensitive to NAADP in the sea urchin egg. Br J Pharmacol 121: 1489-1495. doi:10 $.1038 /$ sj.bjp.0701295

Genazzani AA, Mezna M, Summerhill RJ, Galione A, Michelangeli F. 1997b. Kinetic properties of nicotinic acid adenine dinucleotide phosphate-induced $\mathrm{Ca}^{2+}$ release. $J$ Biol Chem 272: 7669-7675. doi:10.1074/jbc.272.12.7669

Gerasimenko JV, Sherwood M, Tepikin AV, Petersen OH, Gerasimenko OV. 2006. NAADP, cADPR and $\mathrm{IP}_{3}$ all release $\mathrm{Ca}^{2+}$ from the endoplasmic reticulum and an acidic store in the secretory granule area. J Cell Sci 119: 226-238. doi: $10.1242 /$ jcs. 02721

Gerasimenko JV, Charlesworth RM, Sherwood MW, Ferdek PE, Mikoshiba K, Parrington J, Petersen OH, Gerasimenko OV. 2015. Both RyRs and TPCs are required for NAADP-induced intracellular $\mathrm{Ca}^{2+}$ release. Cell Calcium 58: 237-245. doi:10.1016/j.ceca.2015.05.005

Graeff R, Lee HC. 2002. A novel cycling assay for nicotinic acid-adenine dinucleotide phosphate with nanomolar sensitivity. Biochem J 367: 163-168. doi:10.1042/ bj20020644

Graeff R, Liu Q, Kriksunov IA, Hao Q, Lee HC. 2006. Acidic residues at the active sites of $\mathrm{CD} 38$ and ADP-ribosyl cyclase determine nicotinic acid adenine dinucleotide phos- phate (NAADP) synthesis and hydrolysis activities. J Biol Chem 281: 28951-28957. doi:10.1074/jbc.M604370200

Grimm C, Holdt LM, Chen CC, Hassan S, Müller C, Jörs S, Cuny H, Kissing S, Schröder B, Butz E, et al. 2014. High susceptibility to fatty liver disease in two-pore channel 2deficient mice. Nat Commun 5: 4699. doi:10.1038/ ncomms5699

Gunaratne GS, Johns ME, Hintz HM, Walseth TF, Marchant JS. 2018a. A screening campaign in sea urchin egg homogenate as a platform for discovering modulators of NAADP-dependent $\mathrm{Ca}^{2+}$ signaling in human cells. Cell Calcium 75: 42-52. doi:10.1016/j.ceca.2018.08.002

Gunaratne GS, Yang Y, Li F, Walseth TF, Marchant JS. 2018b. NAADP-dependent $\mathrm{Ca}^{2+}$ signaling regulates Middle East respiratory syndrome-coronavirus pseudovirus translocation through the endolysosomal system. Cell Calcium 75: 30-41. doi:10.1016/j.ceca.2018.08.003

Guo J, Zeng W, Chen Q, Lee C, Chen L, Yang Y, Cang C, Ren D, Jiang Y. 2016. Structure of the voltage-gated two-pore channel TPC1 from Arabidopsis thaliana. Nature 531: 196-201. doi:10.1038/nature16446

Guse AH, Diercks BP. 2018. Integration of nicotinic acid adenine dinucleotide phosphate (NAADP)-dependent calcium signalling. J Physiol 596: 2735-2743. doi:10 .1113/JP275974

Huang P, Zou Y, Zhong XZ, Cao Q, Zhao K, Zhu MX, Murrell-Lagnado R, Dong XP. 2014. P2X4 forms functional ATP-activated cation channels on lysosomal membranes regulated by luminal pH. J Biol Chem 289: 17658-17667. doi:10.1074/jbc.M114.552158

Ishibashi K, Suzuki M, Imai M. 2000. Molecular cloning of a novel form (two-repeat) protein related to voltage-gated sodium and calcium channels. Biochem Biophys Res Commun 270: 370-376. doi:10.1006/bbrc.2000.2435

Jardín I, López JJ, Pariente JA, Salido GM, Rosado JA. 2008. Intracellular calcium release from human platelets: Different messengers for multiple stores. Trends Cardiovasc Med 18: 57-61. doi:10.1016/j.tcm.2007.12.004

Jha A, Ahuja M, Patel S, Brailoiu E, Muallem S. 2014. Convergent regulation of the lysosomal two-pore channel-2 by $\mathrm{Mg}^{2+}$, NAADP, PI $(3,5) \mathrm{P}_{2}$ and multiple protein kinases. $E M B O ~ J ~ 33: ~ 501-511$. doi:10.1002/embj.201387035

Kilpatrick BS, Eden ER, Schapira AH, Futter CE, Patel S. 2013. Direct mobilisation of lysosomal $\mathrm{Ca}^{2+}$ triggers complex $\mathrm{Ca}^{2+}$ signals. J Cell Sci 126: 60-66. doi:10.1242/jcs .118836

Kilpatrick BS, Eden ER, Hockey LN, Yates E, Futter CE, Patel S. 2017. An endosomal NAADP-sensitive two-pore $\mathrm{Ca}^{2+}$ channel regulates ER-endosome membrane contact sites to control growth factor signaling. Cell Rep 18: 16361645. doi:10.1016/j.celrep.2017.01.052

Kim BJ, Park KH, Yim CY, Takasawa S, Okamoto H, Im MJ, Kim UH. 2008. Generation of nicotinic acid adenine dinucleotide phosphate and cyclic ADP-ribose by glucagon-like peptide-1 evokes $\mathrm{Ca}^{2+}$ signal that is essential for insulin secretion in mouse pancreatic islets. Diabetes 57: 868-878. doi:10.2337/db07-0443

Kinnear NP, Boittin FX, Thomas JM, Galione A, Evans AM 2004. Lysosome-sarcoplasmic reticulum junctions. A trigger zone for calcium signaling by nicotinic acid adenine dinucleotide phosphate and endothelin-1. J Biol Chem 279: 54319-54326. doi:10.1074/jbc.M406132200 
Kinnear NP, Wyatt CN, Clark JH, Calcraft PJ, Fleischer S, Jeyakumar LH, Nixon GF, Evans AM. 2008. Lysosomes co-localize with ryanodine receptor subtype 3 to form a trigger zone for calcium signalling by NAADP in rat pulmonary arterial smooth muscle. Cell Calcium 44: 190201. doi:10.1016/j.ceca.2007.11.003

Kintzer AF, Stroud RM. 2016. Structure, inhibition and regulation of two-pore channel TPC1 from Arabidopsis thaliana. Nature 531: 258-262. doi:10.1038/nature17194

Krogsaeter EK, Biel M, Wahl-Schott C, Grimm C. 2018. The protein interaction networks of mucolipins and two-pore channels. Biochim Biophys Acta Mol Cell Res 1866: 11111123. doi:10.1016/j.bbamcr.2018.10.020

Lai FA, Erickson HP, Rousseau E, Liu QY, Meissner G. 1988. Purification and reconstitution of the calcium release channel from skeletal muscle. Nature 331: 315-319. doi: $10.1038 / 331315 \mathrm{a} 0$

Lam AK, Galione A. 2013. The endoplasmic reticulum and junctional membrane communication during calcium signaling. Biochim Biophys Acta 1833: 2542-2559. doi:10.1016/j.bbamcr.2013.06.004

Lange I, Yamamoto S, Partida-Sanchez S, Mori Y, Fleig A, Penner R. 2009. TRPM2 functions as a lysosomal $\mathrm{Ca}^{2+}$. release channel in $\beta$ cells. Sci Signal 2: ra23. doi:10.1126/ scisignal.2000278

Langhorst MF, Schwarzmann N, Guse AH. 2004. $\mathrm{Ca}^{2+}$ release via ryanodine receptors and $\mathrm{Ca}^{2+}$ entry: Major mechanisms in NAADP-mediated $\mathrm{Ca}^{2+}$ signaling in Tlymphocytes. Cell Signal 16: 1283-1289. doi:10.1016/j .cellsig.2004.03.013

Lee HC. 2011. Cyclic ADP-ribose and NAADP: Fraternal twin messengers for calcium signaling. Sci China Life Sci 54: 699-711. doi:10.1007/s11427-011-4197-3

Lee HC, Aarhus R. 1995. A derivative of NADP mobilizes calcium stores insensitive to inositol trisphosphate and cyclic ADP-ribose. J Biol Chem 270: 2152-2157. doi:10 $.1074 / j b c .270 .5 .2152$

Lee HC, Aarhus R. 2000. Functional visualization of the separate but interacting calcium stores sensitive to NAADP and cyclic ADP-ribose. J Cell Sci 113: 44134420. doi:10.1007/978-1-4615-0269-2_8

Lee HC, Walseth TF, Bratt GT, Hayes RN, Clapper DL. 1989. Structural determination of a cyclic metabolite of $\mathrm{NAD}^{+}$ with intracellular $\mathrm{Ca}^{2+}$-mobilizing activity. J Biol Chem 264: 1608-1615.

Lee S, Paudel O, Jiang Y, Yang XR, Sham JS. 2015. CD38 mediates angiotensin II-induced intracellular $\mathrm{Ca}^{2+}$ release in rat pulmonary arterial smooth muscle cells. Am J Respir Cell Mol Biol 52: 332-341. doi:10.1165/rcmb .2014-0141OC

Lee CS, Tong BC, Cheng CW, Hung HC, Cheung KH. 2016. Characterization of two-pore channel 2 by nuclear membrane electrophysiology. Sci Rep 6: 20282. doi:10.1038/ srep20282

Lewis AM, Masgrau R, Vasudevan SR, Yamasaki M, O’Neill J S, Garnham C, James K, Macdonald A, Ziegler M, Galione A, et al. 2007. Refinement of a radioreceptor binding assay for nicotinic acid adenine dinucleotide phosphate. Anal Biochem 371: 26-36. doi:10.1016/j.ab.2007.08.030

Lewis AM, Aley PK, Roomi A, Thomas JM, Masgrau R, Garnham C, Shipman K, Paramore C, Bloor-Young D, Sanders LE, et al. 2012. $\beta$-Adrenergic receptor signaling increases NAADP and cADPR levels in the heart. Biochem Biophys Res Commun 427: 326-329. doi:10.1016/j .bbrc.2012.09.054

Lin PH, Duann P, Komazaki S, Park KH, Li H, Sun M, Sermersheim M, Gumpper K, Parrington J, Galione A, et al. 2015. Lysosomal two-pore channel subtype 2 (TPC2) regulates skeletal muscle autophagic signaling. J Biol Chem 290: 3377-3389. doi:10.1074/jbc.M114 .608471

Lin WK, Bolton EL, Cortopassi WA, Wang Y, O’Brien F, Maciejewska M, Jacobson MP, Garnham C, Ruas M, Parrington J, et al. 2017. Synthesis of the $\mathrm{Ca}^{2+}$-mobilizing messengers NAADP and cADPR by intracellular CD38 enzyme in the mouse heart: Role in $\beta$-adrenoceptor signaling. J Biol Chem 292: 13243-13257. doi:10.1074/jbc .M117.789347

Lin-Moshier Y, Keebler MV, Hooper R, Boulware MJ, Liu X, Churamani D, Abood ME, Walseth TF, Brailoiu E, Patel S, et al. 2014. The two-pore channel (TPC) interactome unmasks isoform-specific roles for TPCs in endolysosomal morphology and cell pigmentation. Proc Natl Acad Sci 11: 13087-13092. doi:10.1073/pnas.1407004111

Liu J, Zhao YJ, Li WH, Hou YN, Li T, Zhao ZY, Fang C, Li SL, Lee HC. 2017. Cytosolic interaction of type III human CD38 with CIB1 modulates cellular cyclic ADP-ribose levels. Proc Natl Acad Sci 114: 8283-8288. doi:10.1073/ pnas. 1703718114

Lloyd-Evans E, Morgan AJ, He X, Smith DA, Elliot-Smith E, Sillence DJ, Churchill GC, Schuchman EH, Galione A, Platt FM. 2008. Niemann-Pick disease type C1 is a sphingosine storage disease that causes deregulation of lysosomal calcium. Nat Med 14: 1247-1255. doi:10.1038/ nm.1876

Luzio JP, Pryor PR, Bright NA. 2007. Lysosomes: Fusion and function. Nat Rev Mol Cell Biol 8: 622-632. doi:10.1038/ nrm2217

Macgregor A, Yamasaki M, Rakovic S, Sanders L, Parkesh R, Churchill GC, Galione A, Terrar DA. 2007. NAADP controls cross-talk between distinct $\mathrm{Ca}^{2+}$ stores in the heart. J Biol Chem 282: 15302-15311. doi:10.1074/jbc .M611167200

Mak DO, Foskett JK. 1997. Single-channel kinetics, inactivation, and spatial distribution of inositol trisphosphate $\left(\mathrm{IP}_{3}\right)$ receptors in Xenopus oocyte nucleus. J Gen Physiol 109: 571-587. doi:10.1085/jgp.109.5.571

Malavasi F, Deaglio S, Funaro A, Ferrero E, Horenstein AL, Ortolan E, Vaisitti T, Aydin S. 2008. Evolution and function of the ADP ribosyl cyclase/CD38 gene family in physiology and pathology. Physiol Rev 88: 841-886. doi:10.1152/physrev.00035.2007

Mándi M, Tóth B, Timár G, Bak J. 2006. $\mathrm{Ca}^{2+}$ release triggered by NAADP in hepatocyte microsomes. Biochem J 395: 233-238. doi:10.1042/BJ20051002

Mao C, Kim SH, Almenoff JS, Rudner XL, Kearney DM, Kindman LA. 1996. Molecular cloning and characterization of SCaMPER, a sphingolipid $\mathrm{Ca}^{2+}$ release-mediating protein from endoplasmic reticulum. Proc Natl Acad Sci 93: 1993-1996. doi:10.1073/pnas.93.5.1993

Masgrau R, Churchill GC, Morgan AJ, Ashcroft SJ, Galione A. 2003. NAADP: A new second messenger for glucoseinduced $\mathrm{Ca}^{2+}$ responses in clonal pancreatic $\beta$ cells. Curr Biol 13: 247-251. doi:10.1016/S0960-9822(03)00041-1 
Melchionda M, Pittman JK, Mayor R, Patel S. 2016. $\mathrm{Ca}^{2+} / \mathrm{H}^{+}$ exchange by acidic organelles regulates cell migration in vivo. J Cell Biol 212: 803-813. doi:10.1083/jcb.201510019

Menteyne A, Burdakov A, Charpentier G, Petersen OH, Cancela JM. 2006. Generation of specific $\mathrm{Ca}^{2+}$ signals from $\mathrm{Ca}^{2+}$ stores and endocytosis by differential coupling to messengers. Curr Biol 16: 1931-1937. doi:10.1016/j .cub.2006.07.070

Mitchell KJ, Lai FA, Rutter GA. 2003. Ryanodine receptor type I and nicotinic acid adenine dinucleotide phosphate receptors mediate $\mathrm{Ca}^{2+}$ release from insulin-containing vesicles in living pancreatic $\beta$-cells (MIN6). J Biol Chem 278: 11057-11064. doi:10.1074/jbc.M210257200

Moccia F, Lim D, Nusco GA, Ercolano E, Santella L. 2003. NAADP activates a $\mathrm{Ca}^{2+}$ current that is dependent on $\mathrm{F}$ actin cytoskeleton. FASEB J 17: 1907-1909. doi:10.1096/fj .03-0178fje

Moccia F, Billington RA, Santella L. 2006. Pharmacological characterization of NAADP-induced $\mathrm{Ca}^{2+}$ signals in starfish oocytes. Biochem Biophys Res Commun 348: 329336. doi:10.1016/j.bbrc.2006.05.157

Morgan AJ, Galione A. 2007a. Fertilization and nicotinic acid adenine dinucleotide phosphate induce $\mathrm{pH}$ changes in acidic $\mathrm{Ca}^{2+}$ stores in sea urchin eggs. J Biol Chem 282: 37730-37737. doi:10.1074/jbc.M704630200

Morgan AJ, Galione A. 2007b. NAADP induces pH changes in the lumen of acidic $\mathrm{Ca}^{2+}$ stores. Biochem J 402: 301310. doi:10.1042/BJ20060759

Morgan AJ, Galione A. 2008. Investigating cADPR and NAADP in intact and broken cell preparations. Methods 46: 194-203. doi:10.1016/j.ymeth.2008.09.013

Morgan AJ, Galione A. 2014. Two-pore channels (TPCs): Current controversies. Bioessays 36: 173-183. doi:10 $.1002 /$ bies.201300118

Morgan AJ, Davis LC, Wagner SK, Lewis AM, Parrington J, Churchill GC, Galione A. 2013. Bidirectional $\mathrm{Ca}^{2+}$ signaling occurs between the endoplasmic reticulum and acidic organelles. J Cell Biol 200: 789-805. doi:10.1083/ jcb. 201204078

Naylor E, Arredouani A, Vasudevan SR, Lewis AM, Parkesh R, Mizote A, Rosen D, Thomas JM, Izumi M, Ganesan A, et al. 2009. Identification of a chemical probe for NAADP by virtual screening. Nat Chem Biol 5: 220-226. doi:10 $.1038 /$ nchembio. 150

Ogunbayo OA, Duan J, Xiong J, Wang Q, Feng X, Ma J, Zhu MX, Evans AM. 2018. mTORC1 controls lysosomal Ca ${ }^{2+}$ release through the two-pore channel TPC2. Sci Signal 11: eaao5775. doi:10.1126/scisignal.aao5775

Pandey V, Chuang CC, Lewis AM, Aley PK, Brailoiu E, Dun NJ, Churchill GC, Patel S. 2009. Recruitment of NAADPsensitive acidic $\mathrm{Ca}^{2+}$ stores by glutamate. Biochem $\mathrm{J} 422$ 503-512. doi:10.1042/BJ20090194

Park DR, Park KH, Kim BJ, Yoon CS, Kim UH. 2015. Exercise ameliorates insulin resistance via $\mathrm{Ca}^{2+}$ signals distinct from those of insulin for GLUT4 translocation in skeletal muscles. Diabetes 64: 1224-1234. doi:10.2337/db14-0939

Patel S, Docampo R. 2010. Acidic calcium stores open for business: Expanding the potential for intracellular $\mathrm{Ca}^{2+}$ signaling. Trends Cell Biol 20: 277-286. doi:10.1016/j.tcb .2010 .02 .003
Patel S, Churchill GC, Galione A. 2001. Coordination of $\mathrm{Ca}^{2+}$ signalling by NAADP. Trends Biochem Sci 26: 482-489. doi:10.1016/S0968-0004(01)01896-5

Patel S, Penny CJ, Rahman T. 2016. Two-pore channels enter the atomic era: Structure of plant TPC revealed. Trends Biochem Sci 41: 475-477. doi:10.1016/j.tibs.2016.04.007

Peiter E, Maathuis FJ, Mills LN, Knight H, Pelloux J, Hetherington AM, Sanders D. 2005. The vacuolar $\mathrm{Ca}^{2+}$-activated channel TPC1 regulates germination and stomatal movement. Nature 434: 404-408. doi:10.1038/nature03381

Penny CJ, Kilpatrick BS, Eden ER, Patel S. 2015. Coupling acidic organelles with the ER through $\mathrm{Ca}^{2+}$ microdomains at membrane contact sites. Cell Calcium 58: 387396. doi:10.1016/j.ceca.2015.03.006

Penny CJ, Vassileva K, Jha A, Yuan Y, Chee X, Yates E, Mazzon M, Kilpatrick BS, Muallem S, Marsh M, et al. 2018. Mining of Ebola virus entry inhibitors identifies approved drugs as two-pore channel pore blockers. Biochim Biophys Acta Mol Cell Res 1866: 1151-1161. doi:10 .1016/j.bbamcr.2018.10.022

Pereira GJ, Hirata H, Fimia GM, do Carmo LG, Bincoletto C, Han SW, Stilhano RS, Ureshino RP, Bloor-Young D, Churchill G, et al. 2011. Nicotinic acid adenine dinucleotide phosphate (NAADP) regulates autophagy in cultured astrocytes. J Biol Chem 286: 27875-27881. doi:10.1074/ jbc.C110.216580

Pereira GJ, Antonioli M, Hirata H, Ureshino RP, Nascimento AR, Bincoletto C, Vescovo T, Piacentini M, Fimia GM, Smaili SS. 2017. Glutamate induces autophagy via the two-pore channels in neural cells. Oncotarget 8: 1273012740. doi:10.18632/oncotarget.14404

Piper RC, Luzio JP. 2004. CUPpling calcium to lysosomal biogenesis. Trends Cell Biol 14: 471-473. doi:10.1016/j.tcb .2004 .07 .010

Pitt SJ, Funnell TM, Sitsapesan M, Venturi E, Rietdorf K, Ruas M, Ganesan A, Gosain R, Churchill GC, Zhu MX, et al. 2010. TPC2 is a novel NAADP-sensitive $\mathrm{Ca}^{2+}$ release channel, operating as a dual sensor of luminal $\mathrm{pH}$ and $\mathrm{Ca}^{2+}$. J Biol Chem 285: 35039-35046. doi:10.1074/jbc .M110.156927

Pitt SJ, Lam AK, Rietdorf K, Galione A, Sitsapesan R. 2014. Reconstituted human TPC1 is a proton-permeable ion channel and is activated by NAADP or $\mathrm{Ca}^{2+}$. Sci Signal 7: ra46. doi:10.1126/scisignal.2004854

Pitt SJ, Reilly-O’Donnell B, Sitsapesan R. 2016. Exploring the biophysical evidence that mammalian two-pore channels are NAADP-activated calcium-permeable channels. $J$ Physiol 594: 4171-4179. doi:10.1113/JP270936

Pozzan T, Rizzuto R, Volpe P, Meldolesi J. 1994. Molecular and cellular physiology of intracellular calcium stores. Physiol Rev 74: 595-636. doi:10.1152/physrev.1994.74.3 .595

Pryor PR, Reimann F, Gribble FM, Luzio JP. 2006. Mucolipin-1 is a lysosomal membrane protein required for intracellular lactosylceramide traffic. Traffic 7: 1388-1398. doi:10.1111/j.1600-0854.2006.00475.x

Qureshi OS, Paramasivam A, Yu JC, Murrell-Lagnado RD. 2007. Regulation of P2X4 receptors by lysosomal targeting, glycan protection and exocytosis. J Cell Sci 120:38383849. doi: $10.1242 /$ jcs. 010348

Rah SY, Mushtaq M, Nam TS, Kim SH, Kim UH. 2010. Generation of cyclic ADP-ribose and nicotinic acid ade- 
nine dinucleotide phosphate by $\mathrm{CD} 38$ for $\mathrm{Ca}^{2+}$ signaling in interleukin-8-treated lymphokine-activated killer cells. J Biol Chem 285: 21877-21887. doi:10.1074/jbc.M109 .066290

Rah SY, Lee YH, Kim UH. 2017. NAADP-mediated $\mathrm{Ca}^{2+}$ signaling promotes autophagy and protects against LPSinduced liver injury. FASEB J 31:3126-3137. doi:10.1096/ fj.201601290R

Rietdorf K, Funnell TM, Ruas M, Heinemann J, Parrington J, Galione A. 2011. Two-pore channels form homo- and heterodimers. J Biol Chem 286: 37058-37062. doi:10 $.1074 /$ jbc.C111.289835

Rizzuto R, Pinton P, Carrington W, Fay FS, Fogarty KE, Lifshitz LM, Tuft RA, Pozzan T. 1998. Close contacts with the endoplasmic reticulum as determinants of mitochondrial $\mathrm{Ca}^{2+}$ responses. Science 280: $1763-1766$. doi:10.1126/science.280.5370.1763

Rosen D, Lewis AM, Mizote A, Thomas JM, Aley PK, Vasudevan SR, Parkesh R, Galione A, Izumi M, Ganesan A, et al. 2009. Analogues of the nicotinic acid adenine dinucleotide phosphate (NAADP) antagonist Ned-19 indicate two binding sites on the NAADP receptor. J Biol Chem 284: 34930-34934. doi:10.1074/jbc.M109.016519

Ruas M, Rietdorf K, Arredouani A, Davis LC, Lloyd-Evans E, Koegel H, Funnell TM, Morgan AJ, Ward JA, Watanabe $\mathrm{K}$, et al. 2010. Purified TPC isoforms form NAADP receptors with distinct roles for $\mathrm{Ca}^{2+}$ signaling and endolysosomal trafficking. Curr Biol 20: 703-709. doi:10.1016/j .cub.2010.02.049

Ruas M, Davis LC, Chen CC, Morgan AJ, Chuang KT, Walseth TF, Grimm C, Garnham C, Powell T, Platt N, et al. 2015. Expression of $\mathrm{Ca}^{2+}$-permeable two-pore channels rescues NAADP signalling in TPC-deficient cells. $E M B O$ J 34: 1743-1758. doi:10.15252/embj.201490009

Rutter GA. 2003. Calcium signalling: NAADP comes out of the shadows. Biochem J 373: e3-e4. doi:10.1042/ bj20030472COM

Sakurai Y, Kolokoltsov AA, Chen CC, Tidwell MW, Bauta WE, Klugbauer N, Grimm C, Wahl-Schott C, Biel M, Davey RA. 2015. Ebola virus. Two-pore channels control Ebola virus host cell entry and are drug targets for disease treatment. Science 347: 995-998. doi:10.1126/science .1258758

Samie MA, Grimm C, Evans JA, Curcio-Morelli C, Heller S, Slaugenhaupt SA, Cuajungco MP. 2009. The tissue-specific expression of TRPML2 (MCOLN-2) gene is influenced by the presence of TRPML1. Pflugers Arch 459: 79-91. doi:10.1007/s00424-009-0716-5

Schieder M, Rötzer K, Brüggemann A, Biel M, Wahl-Schott CA. 2010. Characterization of two-pore channel 2 (TPCN2)-mediated $\mathrm{Ca}^{2+}$ currents in isolated lysosomes. J Biol Chem 285: 21219-21222. doi:10.1074/jbc.C110 .143123

Schmid F, Bruhn S, Weber K, Mittrücker HW, Guse AH. 2011. CD38: A NAADP degrading enzyme. FEBS Let 585: 3544-3548. doi:10.1016/j.febslet.2011.10.017

Schmid F, Fliegert R, Westphal T, Bauche A, Guse AH. 2012. Nicotinic acid adenine dinucleotide phosphate (NAADP) degradation by alkaline phosphatase. J Biol Chem 287: 32525-32534. doi:10.1074/jbc.M112.362715

Schnurbus R, de Pietri Tonelli D, Grohovaz F, Zacchetti D. 2002. Re-evaluation of primary structure, topology, and localization of Scamper, a putative intracellular $\mathrm{Ca}^{2+}$ channel activated by sphingosylphosphocholine. Biochem J 362: 183-189. doi:10.1042/bj3620183

Shapovalov G, Ritaine A, Bidaux G, Slomianny C, Borowiec AS, Gordienko D, Bultynck G, Skryma R, Prevarskaya N. 2017. Organelle membrane derived patches: Reshaping classical methods for new targets. Sci Rep 7: 14082. doi:10.1038/s41598-017-13968-y

She J, Guo J, Chen Q, Zeng W, Jiang Y, Bai XC. 2018. Structural insights into the voltage and phospholipid activation of the mammalian TPC1 channel. Nature 556: 130-134. doi:10.1038/nature26139

She J, Zeng W, Guo J, Chen Q, Bai XC, Jiang Y. 2019. Structural mechanisms of phospholipid activation of the human TPC2 channel. eLife 8: e45222. doi:10.7554/eLife .45222

Soares S, Thompson M, White T, Isbell A, Yamasaki M, Prakash Y, Lund FE, Galione A, Chini EN. 2007. NAADP as a second messenger: Neither CD38 nor base-exchange reaction are necessary for in vivo generation of NAADP in myometrial cells. Am J Physiol Cell Physiol 292: C227C239. doi:10.1152/ajpcell.00638.2005

Streb H, Irvine RF, Berridge MJ, Schulz I. 1983. Release of $\mathrm{Ca}^{2+}$ from a nonmitochondrial intracellular store in pancreatic acinar cells by inositol-1,4,5-trisphosphate. Nature 306: 67-69. doi:10.1038/306067a0

Striggow F, Ehrlich BE. 1997. Regulation of intracellular calcium release channel function by arachidonic acid and leukotriene B4. Biochem Biophys Res Commun 237: 413-418. doi:10.1006/bbrc.1997.7152

Sun W, Yue J. 2018. TPC2 mediates autophagy progression and extracellular vesicle secretion in cancer cells. Exp Cell Res 370: 478-489. doi:10.1016/j.yexcr.2018.07.013

Taylor CW, Prole DL, Rahman T. 2009. $\mathrm{Ca}^{2+}$ channels on the move. Biochemistry 48: 12062-12080. doi:10.1021/ bi901739t

Thai TL, Churchill GC, Arendshorst WJ. 2009. NAADP receptors mediate calcium signaling stimulated by endothelin-1 and norepinephrine in renal afferent arterioles. Am J Physiol Renal Physiol 297: F510-F516. doi:10.1152/ ajprenal.00116.2009

Tugba Durlu-Kandilci N, Ruas M, Chuang KT, Brading A, Parrington J, Galione A. 2010. TPC2 proteins mediate nicotinic acid adenine dinucleotide phosphate (NAADP)- and agonist-evoked contractions of smooth muscle. J Biol Chem 285: 24925-24932. doi:10.1074/jbc .M110.129833

Wagner LE II, Groom LA, Dirksen RT, Yule DI. 2014. Characterization of ryanodine receptor type 1 single channel activity using "on-nucleus" patch clamp. Cell Calcium 56: 96-107. doi:10.1016/j.ceca.2014.05.004

Walseth TF, Lin-Moshier Y, Jain P, Ruas M, Parrington J, Galione A, Marchant JS, Slama JT. 2012a. Photoaffinity labeling of high affinity nicotinic acid adenine dinucleotide phosphate (NAADP)-binding proteins in sea urchin egg. J Biol Chem 287: 2308-2315. doi:10.1074/jbc.M111 .306563

Walseth TF, Lin-Moshier Y, Weber K, Marchant JS, Slama JT, Guse AH. 2012b. Nicotinic acid adenine dinucleotide $2^{\prime}$-phosphate (NAADP) binding proteins in T-lymphocytes. Messenger (Los Angel) 1: 86-94. doi:10.1166/msr .2012 .1008 
NAADP Receptors

Wang X, Zhang X, Dong XP, Samie M, Li X, Cheng X, Goschka A, Shen D, Zhou Y, Harlow J, et al. 2012. TPC proteins are phosphoinositide-activated sodiumselective ion channels in endosomes and lysosomes. Cell 151: 372-383. doi:10.1016/j.cell.2012.08.036

Whitaker M, Irvine RF. 1984. Inositol 1,4,5 trisphosphate microinjection activates sea urchin eggs. Nature 312: 636-639. doi:10.1038/312636a0

Xu H, Ren D. 2015. Lysosomal physiology. Annu Rev Physiol 77: 57-80. doi:10.1146/annurev-physiol-021014-071649

Yamaguchi S, Jha A, Li Q, Soyombo AA, Dickinson GD, Churamani D, Brailoiu E, Patel S, Muallem S. 2011. Transient receptor potential mucolipin 1 (TRPML1) and twopore channels are functionally independent organellar ion channels. J Biol Chem 286: 22934-22942. doi:10 $.1074 / \mathrm{jbc} . \mathrm{M} 110.210930$

Yamasaki M, Masgrau R, Morgan AJ, Churchill GC, Patel S, Ashcroft SJ, Galione A. 2004. Organelle selection determines agonist-specific $\mathrm{Ca}^{2+}$ signals in pancreatic acinar and $\beta$ cells. J Biol Chem 279: 7234-7240. doi:10.1074/jbc .M311088200

Yamasaki M, Thomas JM, Churchill GC, Garnham C, Lewis AM, Cancela JM, Patel S, Galione A. 2005. Role of NAADP and CADPR in the induction and maintenance of agonistevoked Ca ${ }^{2+}$ spiking in mouse pancreatic acinar cells. Curr Biol 15: 874-878. doi:10.1016/j.cub.2005.04.033

Yue J, Wei W, Lam CM, Zhao YJ, Dong M, Zhang LR, Zhang LH, Lee HC. 2009. CD38/cADPR/Ca ${ }^{2+}$ pathway promotes cell proliferation and delays nerve growth factorinduced differentiation in PC12 cells. J Biol Chem 284: 29335-29342. doi:10.1074/jbc.M109.049767

Zhang F, Li PL. 2007. Reconstitution and characterization of a nicotinic acid adenine dinucleotide phosphate
(NAADP)-sensitive $\mathrm{Ca}^{2+}$ release channel from liver lysosomes of rats. J Biol Chem 282: 25259-25269. doi:10 $.1074 /$ jbc.M701614200

Zhang F, Zhang G, Zhang AY, Koeberl MJ, Wallander E, Li PL. 2006. Production of NAADP and its role in $\mathrm{Ca}^{2+}$ mobilization associated with lysosomes in coronary arterial myocytes. Am J Physiol Heart Circ Physiol 291: H274H282. doi:10.1152/ajpheart.01064.2005

Zhang F, Jin S, Yi F, Li PL. 2009. TRP-ML1 functions as a lysosomal NAADP-sensitive $\mathrm{Ca}^{2+}$ release channel in coronary arterial myocytes. J Cell Mol Med 13: 3174-3185. doi:10.1111/j.1582-4934.2008.00486.x

Zhang F, Xia M, Li PL. 2010. Lysosome-dependent $\mathrm{Ca}^{2+}$ release response to Fas activation in coronary arterial myocytes through NAADP: Evidence from CD38 gene knockouts. Am J Physiol Cell Physiol 298: C1209C1216. doi:10.1152/ajpcell.00533.2009

Zhang B, Watt JM, Cordiglieri C, Dammermann W, Mahon MF, Flugel A, Guse AH, Potter BVL. 2018. Small molecule antagonists of NAADP-induced $\mathrm{Ca}^{2+}$ release in T-lymphocytes suggest potential therapeutic agents for autoimmune disease. Sci Rep 8: 16775. doi:10.1038/ s41598-018-34917-3

Zhu MX, Ma J, Parrington J, Calcraft PJ, Galione A, Evans AM. 2010. Calcium signaling via two-pore channels: Local or global, that is the question. Am J Physiol Cell Physiol 298: C430-C441. doi:10.1152/ajpcell.00475.2009

Zong X, Schieder M, Cuny H, Fenske S, Gruner C, Rötzer K, Griesbeck O, Harz H, Biel M, Wahl-Schott C. 2009. The two-pore channel TPCN2 mediates NAADP-dependent $\mathrm{Ca}^{2+}$-release from lysosomal stores. Pflugers Arch 458: 891-899. doi:10.1007/s00424-009-0690-y 


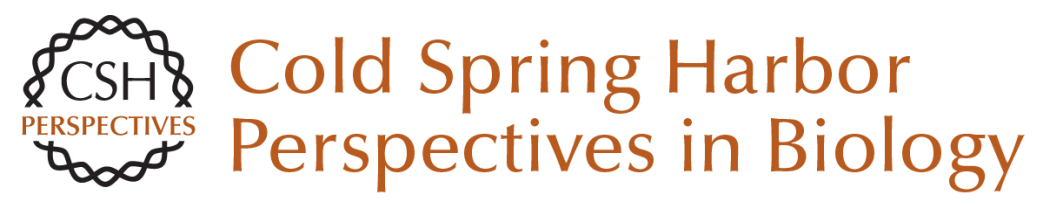

\section{NAADP Receptors}

Antony Galione

Cold Spring Harb Perspect Biol 2019; doi: 10.1101/cshperspect.a035071 originally published online June 10, 2019

\section{Subject Collection Calcium Signaling}

The Endoplasmic Reticulum-Plasma Membrane Junction: A Hub for Agonist Regulation of $\mathrm{Ca}^{2+}$ Entry

Hwei Ling Ong and Indu Suresh Ambudkar

Calcium-Handling Defects and Neurodegenerative Disease

Sean Schrank, Nikki Barrington and Grace E. Stutzmann

Lysosomal $\mathrm{Ca}^{2+}$ Homeostasis and Signaling in Health and Disease

Emyr Lloyd-Evans and Helen Waller-Evans

\section{$\mathrm{Ca}^{2+}$ Signaling in Exocrine Cells}

Malini Ahuja, Woo Young Chung, Wei-Yin Lin, et al.

Functional Consequences of Calcium-Dependent Synapse-to-Nucleus Communication: Focus on Transcription-Dependent Metabolic Plasticity Anna M. Hagenston, Hilmar Bading and Carlos Bas-Orth

Identifying New Substrates and Functions for an Old Enzyme: Calcineurin Jagoree Roy and Martha S. Cyert

Fundamentals of Cellular Calcium Signaling: A Primer

Martin D. Bootman and Geert Bultynck
Primary Active $\mathrm{Ca}^{2+}$ Transport Systems in Health and Disease Jialin Chen, Aljona Sitsel, Veronick Benoy, et al.

Signaling through $\mathrm{Ca}^{2+}$ Microdomains from Store-Operated CRAC Channels Pradeep Barak and Anant B. Parekh

Structural Insights into the Regulation of $\mathrm{Ca}^{2+}$ /Calmodulin-Dependent Protein Kinase II (CaMKII) Moitrayee Bhattacharyya, Deepti Karandur and John Kuriyan

Store-Operated Calcium Channels: From Function to Structure and Back Again Richard S. Lewis

Bcl-2-Protein Family as Modulators of $\mathrm{IP}_{3}$

Receptors and Other Organellar $\mathrm{Ca} 2+$ Channels Hristina Ivanova, Tim Vervliet, Giovanni Monaco, et al.

Calcium Signaling in Cardiomyocyte Function Guillaume Gilbert, Kateryna Demydenko, Eef Dries, et al.

Cytosolic $\mathrm{Ca}^{2+}$ Buffers Are Inherently $\mathrm{Ca}^{2+}$ Signal Modulators Beat Schwaller

For additional articles in this collection, see http://cshperspectives.cshlp.org/cgi/collection/

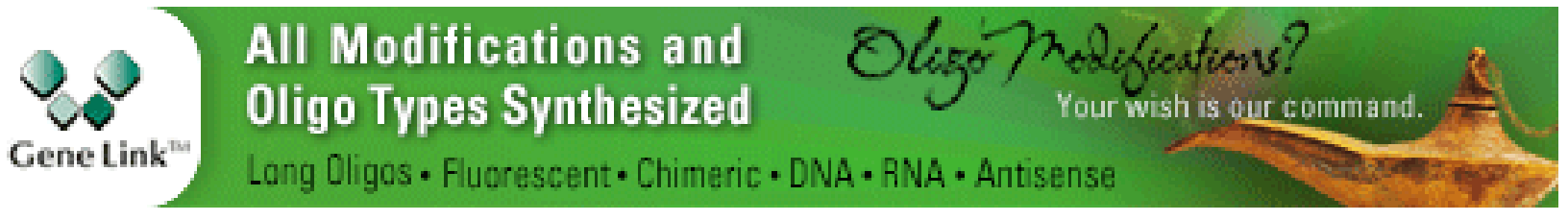


Role of Two-Pore Channels in Embryonic Development and Cellular Differentiation Sarah E. Webb, Jeffrey J. Kelu and Andrew L. Miller

\section{Organellar Calcium Handling in the Cellular \\ Reticular Network}

Wen-An Wang, Luis B. Agellon and Marek Michalak

For additional articles in this collection, see http://cshperspectives.cshlp.org/cgi/collection/

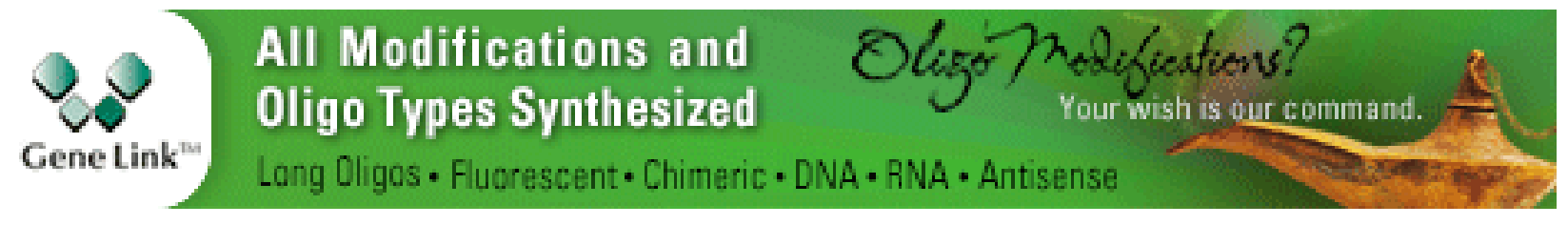

Copyright @ 2019 Cold Spring Harbor Laboratory Press; all rights reserved 